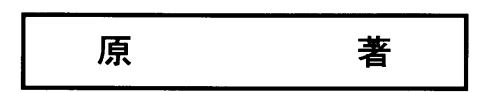

\title{
口垛粘膜病変の硬さ測定に関する研究
}

\author{
佐 藤仁 \\ 東京医科歯科大学歯学部口腔外科学第 1 講座（主任・指導：天笠光雄教授）
}

(1994 年 3 月 29 日 受付)

\section{A Study on Measurement of Hardness of Oral Mucosal Lesions}

\author{
Masashi Sato \\ The First Department of Oral and Maxillofacial Surgery, Faculty of Dentistry, \\ Tokyo Medical and Dental University \\ (Chief and Director: Prof. Teruo Amagasa)
}

\begin{abstract}
This study was designed to estimate objectively the hardness of the oral mucosa which is not directly supported by the bone. A new, easy-to-use hardness-measurement apparatus for measuring the oral mucosa free of the underlining bone was manufactured for trial use. The hardness values of the oral mucosa were evaluated quantitatively, resulting from pressing $2 \mathrm{~mm}$ into the mucosa with a 2-mm-in-diameter hand-held probe coupled to the hardness-measurement apparatus. Experimental and clinical confirmation was made that practical errors in hardness values are quite permissible when using this apparatus. This fool-proof method was further examined in extensive clinical application.

The normal mucous membrane of the tongue, the floor of the mouth, and the cheek respectively measure $4.45,4.33$, and $2.96 \mathrm{gf}$ on average with this apparatus. Examining 26 cases of squamous cell carcinoma on the tongue, the floor of the mouth or the buccal mucosa (16.87 $\sim 80.32$ gf) revealed that the value of measurement of squamous cell carcinoma was as much as 2.31-19.06 times in comparison with the normal mucous membrane. Squamous cell carcinomas were ascertained to be statistically harder than the normal mucosa $(\mathrm{p}<0.001)$ and the tumor margins may be far more precisely clarified with this apparatus than with the human finger alone.
\end{abstract}

\section{I 。緒言}

口腔粘膜病変の診断においては, 視診, 触診は 重要な所見である。口腔疾患のあるものでは特有 の硬さを有すると推察されているが，これまで必 ずしも明らかとなっていない。骨に直接裏打ちさ れていない口腔粘膜癌の診断における硬結の有無
は, 臨床診断上, 重要とされているが, 客観的, 定量的に表示・記録することは全く不可能であっ た。皮膚あるいは経皮的な生体硬さの臨床的測定 法に関する報告 ${ }^{1 \sim 4,10 ~ 18)}$, および胃や大腸の粘膜の 測定を試みた報告はあるが ${ }^{19,20)}$ ，精度や方法に問 題があり，口腔では応用しがたいものであった。 そこで著者は口腔粘膜の硬さ測定方法について検 
討し, 硬さ測定のための器機を考案試作し, 可動 部の正常口腔粘膜と病変の硬さを測定し, 診断に 応用することを試みた。

\section{II. 研究対象}

\section{1. 予借的計測のための症例}

健常者舌側縁 5 例, 舌扁平上皮癌 2 例を対象と した。

\section{2. 健常粘膜}

視診にて異常を認めない 24 48 歳の健常成人 25 名 (男性 14 名, 女性 11 名) で, 測定部位は舌, 口底, 煩粘膜とした。

\section{3. 口腔粘膜疾患}

平成 4 年 3 月より平成 5 年 10 月までに当科を 受診した扁平上皮癌一次症例 26 例, 白板症 4 例, 扁平苔痽 5 例を対象とした。扁平上皮癌の内訳は, 舌癌 20 例, 口底癌 3 例, 煩粘膜癌 3 例であった。 白板症は, 舌 2 例, 頓粘膜, 口唇各 1 例で, 扁平 苔㿏は, 頖粘膜 4 例と舌 1 例であった。また, 手 術的に切除した舌癌, 口底癌各 2 例, 煩粘膜癌 1 例の計 5 例を切除前後の計測に用いた（表 1 ）。
表 1 対象症例

\begin{tabular}{l|cc|c}
\hline \hline & 男 & 女 & 計 \\
\hline 健常者 & 14 & 11 & 25 \\
扁平上皮癌 & 15 & 11 & 26 \\
$\quad$ (舌) & $(12)$ & $(8)$ & $(20)$ \\
$\quad$ (煩粘膜) & $(1)$ & $(2)$ & $(3)$ \\
$\quad$ (口底) & $(2)$ & $(1)$ & $(3)$ \\
白板症 & & 4 & 4 \\
扁平苔癖 & & 5 & 5 \\
\hline \multicolumn{1}{c|}{ 計 } & 29 & 31 & 60 \\
\hline
\end{tabular}

\section{III. 研究方法}

フリーハンドによる変位一荷重方式にて硬さを 測定する方法を採用し, 硬さ測定器を試作し, 精 度, 再現性, 操作性などを検討した。本法で用い た変位一荷重方式は, 図 1 に示すごとく粘膜の変 位量に対する荷重を硬さとして表示・測定する方 法である。

\section{1. 測定機の試作}

1) 試作装置 1

口腔粘膜を試験的に一定量圧接し, その荷重を

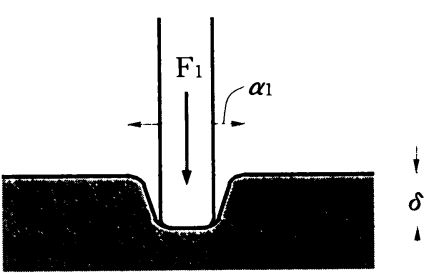

軟らかい組織への圧接

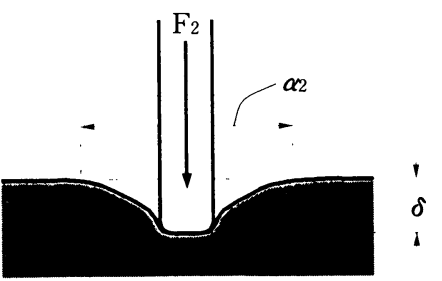

硬い組織への圧接

$$
\begin{aligned}
\mathrm{P} & : \text { 探触子先端 } \\
\alpha_{1}<\alpha_{2} & \text { 変位範囲 } \\
\delta & : \text { 変位量 } \\
\mathrm{F}_{1}<\mathrm{F}_{2} & : \text { 荷重 }
\end{aligned}
$$

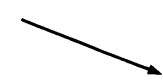

図 1 圧接測定様式（変位量一定） 


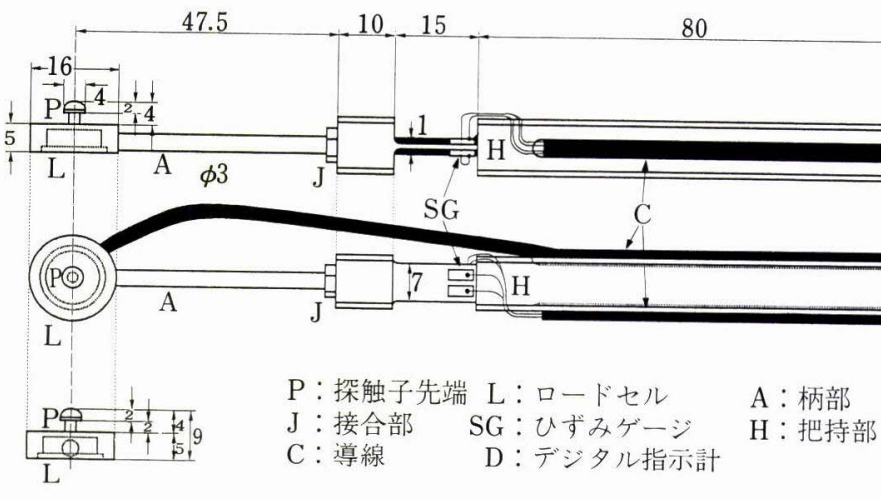

困 2 試作装置 1 の探触子設計困

測定するために圧縮型ロードセル（以後ロードセ ルと略す）を探触子に利用し，さらに把持部との 間にひずみゲージを組み込んだ装置を考案試作し た(総合計装(侏製)。図 2 は本装置の探触子の設計 図で，図 3 は探触子を示したものである。探触子 先端は, 直径 $4 \mathrm{~mm}$ の半球状で，粘膜に圧接する ことにより生じた荷重をひずみゲージにて検出 し, その荷重に対応する電圧をデジタル指示計(印

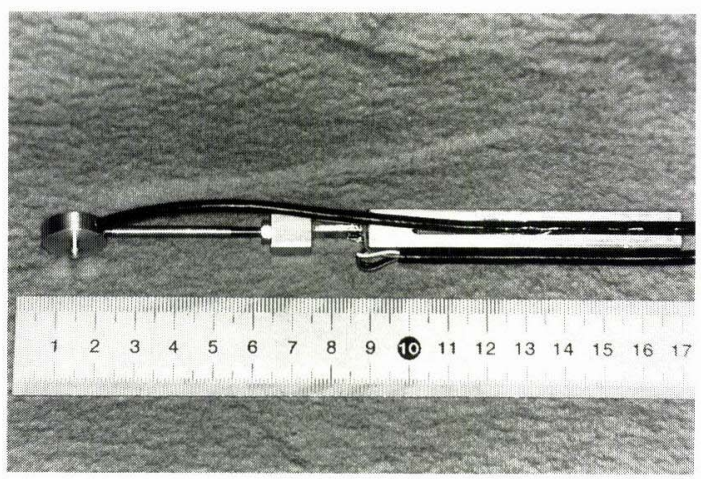

図 3 試作装置 1 の探触子

加電圧 DC $10 \mathrm{~V}$ で歪ゲージセンサーより得た電 圧差を演算し, バイポーラでアナログ出力, さら にピークホールドにて荷重表示）で記録・表示し た。ロードセルならびに歪ゲージ部は, アルミニ ウム製で, 測定可能範囲はロードセルでは，0. 1〜300.0 gf，Uずみゲージで士300.0 gf である。 困4のブロックダイヤグラムに示すようにロード

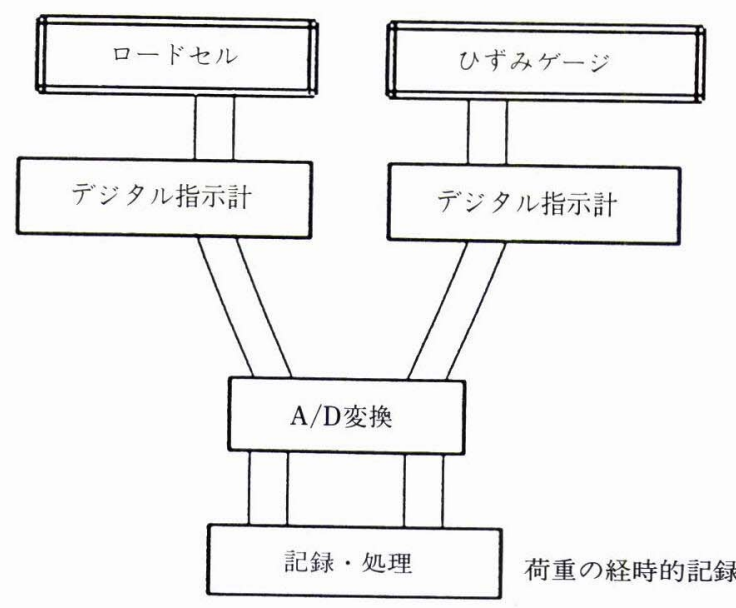

困 4 システム・ブロック・ダイヤグラム

セルとUずみゲージにそれぞれデジタル指示計 （F $360 \mathrm{~A}$ ，ユニパルス）を接続し荷重によって生 じた電圧を $\mathrm{AD}$ ボード $(\mathrm{AD} 12$-16 TA $98 \mathrm{H}$ ，コ ンテック）により $\mathrm{A} / \mathrm{D}$ 変換後，パーソナルコン ピュータ (PC $9801 \mathrm{NA} / \mathrm{C}$, 日本電気) に $5 \mathrm{msec}$ 間隔で 3 秒間取り込んだ。

本装置を使用し，口腔粘膜を測定する際に，唾 液による污染防止のため菲薄なラテックス（厚さ $0.02 \mathrm{~mm}$ コンドーム，オカモト社製）で周囲を被 覆し, フリーハンドで約 $2 \mathrm{~mm}$ 変位した部位まで 圧接し，その時点の荷重（デジタル指示計ピーク ホールド值）を測定した。

2）試作装置 2 


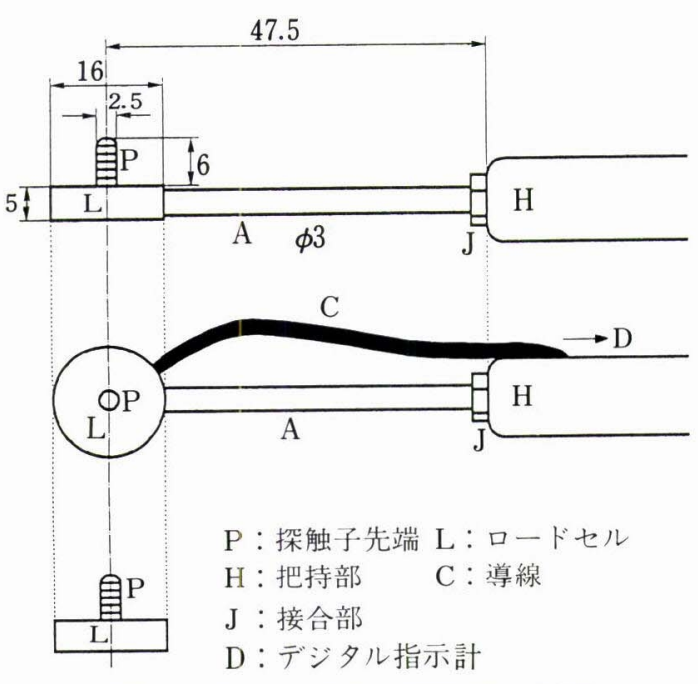

図 5 試作装置 2 の探触子設計図

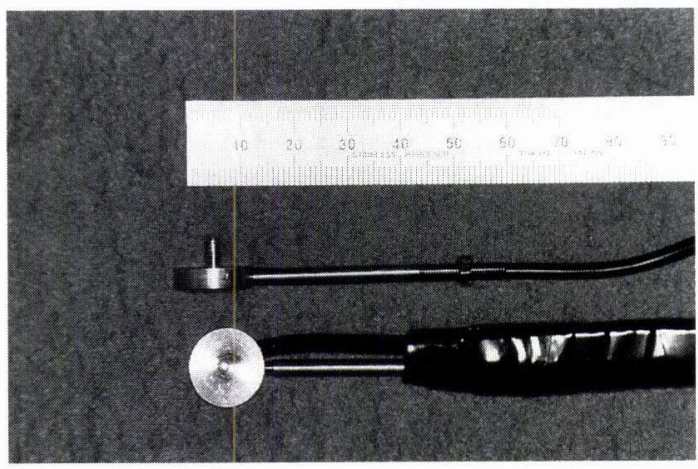

図 6 試作装置 2 の探触子

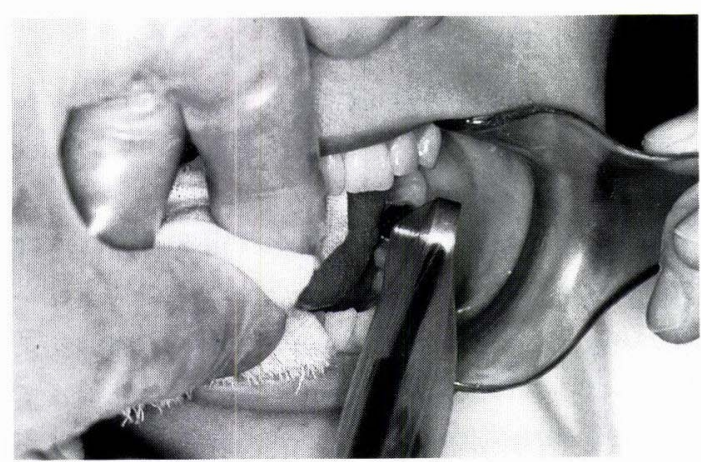

図 7 試作装置 2 による健常者左舌縁部測定 （菲薄ラテックスにて被覆）
試作装置 1 と同様の装置であるが，ロードセル の探触子のみを改良使用し, 探触子の先端の直径 を $2.5 \mathrm{~mm}$ とし, $1.0 \mathrm{~mm}$ 間隔に目盛りを入れた (総合計装(侏)製) (図 5，6 )。なお，他の器機お よび $\mathrm{AD}$ ボードへの接続は試作装置 1 と同様で, 困 7 のごとく舌側縁の測定を試みた。

3）試作装置 3

ロードセルの探触子のかわりにスプリングを組 み込んだ可動性探触子を試作し, 探触子に加わっ た荷重をひずみゲージで読み取る装置を考案作製

(総合計装侏)製）し，その変位と荷重の関係から 硬さの測定を試みた。なお, 探触子先端は消毒の ために接合部より着脱可能とした。図 8 は可動性 探触子の断面図で探触子先端の直径は $2.5 \mathrm{~mm}$, スプリングによる先端の可動範囲は $3.5 \mathrm{~mm}$ で あり，スプリングの強さを $10,20,30,40,50 \mathrm{gf}$ (3.5 mm 圧縮)の 5 種類に設定した。困 9 は試作 装置 3 の設計困であり, 図 10 は装置を示したもの で，図 4 と同様に接続した。Uずみゲージの測定 可能範囲は 0.01 100.00 gf である。硬さ測定は Uずみゲージに接続したスプリングへッド（エチ レンオキサイド・ガス滅菌）の探触子全体がみえ なくなるまで検体に圧接し, その位置での荷重 (デ ジタル指示計ピークホールド值)を測定值とした。

4) 試作装置 4

探触子先端の材質を金属から視認性のよい白色 合成樹脂に変更した。なお, 探触子先端は接合部 より着脱可能とした。図 11 に試作装置 4 の探触子 設計図を示す。探触子先端の直径が $2 \mathrm{~mm}$ で先端 の角には軽微な丸みを付け, 先端から $2 \mathrm{~mm}$ の部

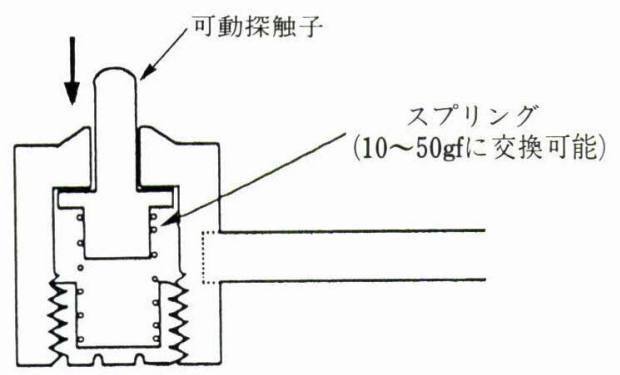

図 8 試作装置 3 の探触子断面図 


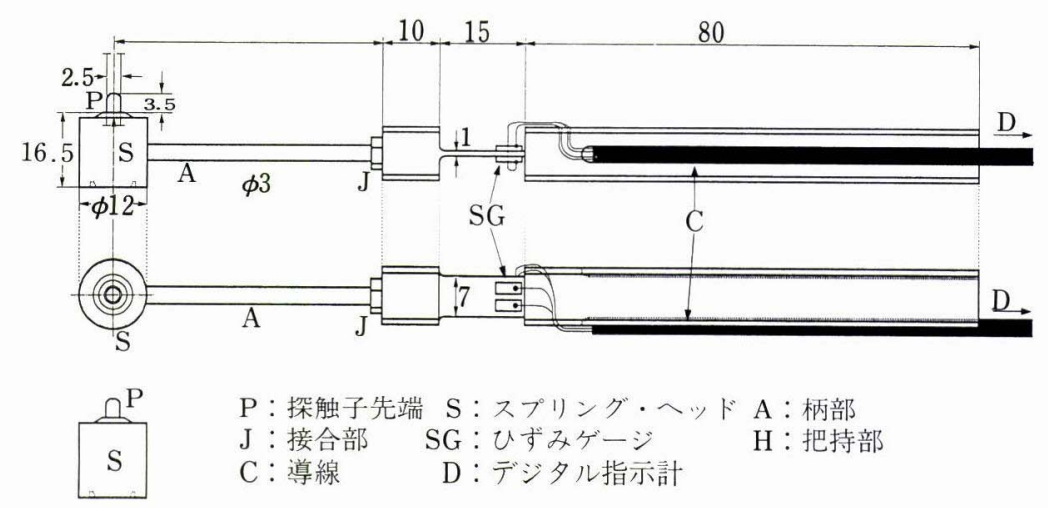

困 9 試作装置 3 の探触子設計図

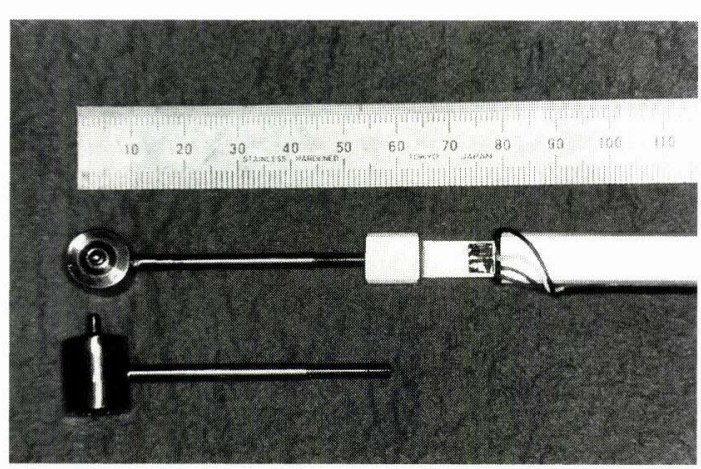

図 10 試作装置 3 の探触子

位に円盤状の読み取り補助板を付与し， $2 \mathrm{~mm} の$ 変位を読み取りやすくした(図 12)。Uずみゲージ の測定可能範囲は 0.01〜100.00 gf で, 図 13 は,
口腔粘膜硬さ測定装置（システム）を示したもの である。図 14 は, 健常者舌側縁を測定していると ころであり,フリーハンドで約 $2 \mathrm{~mm}$ 変位した位 置まで圧接し, その位置で得られた荷重（デジ夕 ル指示計ピークホールド值）を測定した。

\section{2. 探触子の大きさの検討}

探触子先端の直径を $0.5,1.0,1.5,2.0,2.5$, $3.0,4.0 \mathrm{~mm}$ として 7 種類試作し, 健常者 5 名の 舌粘膜に $0.5 \sim 6 \mathrm{~mm}$ 圧接して, 压痕が残るか否 か肉眼的に判定した。

\section{3. 測定機の精度の検討}

デジタル指示計の等価入力較正值は, 設定範囲 $0.500 \mathrm{mV} / \mathrm{V} \sim 3.200 \mathrm{mV} / \mathrm{V}$ で䛊差 $0.1 \% \mathrm{~F} . \mathrm{S}$. (full scale) 以内で，サンプルホールド・ピーク ホールドの動作速度は, 約 $10 \mathrm{kHz}$, 確度は $0.1 \%$
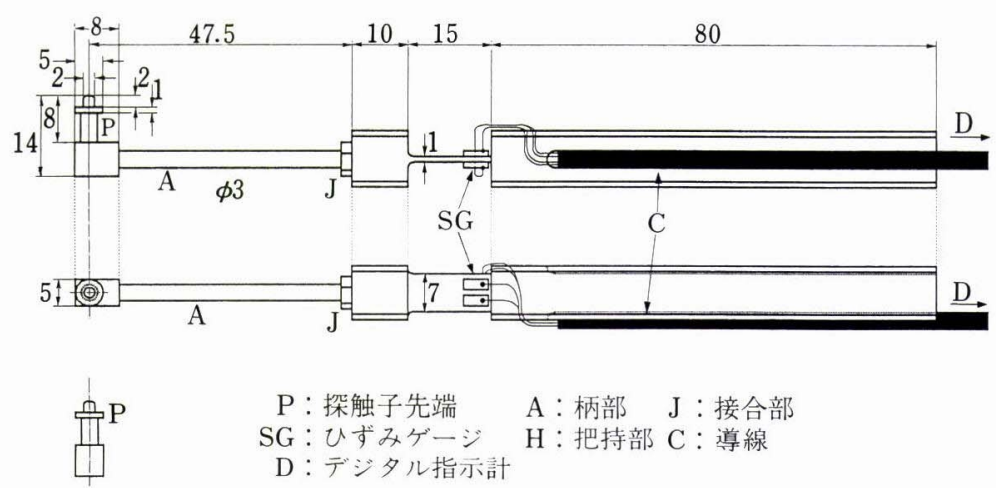

困 11 試作装置 4 の探触子設計図 


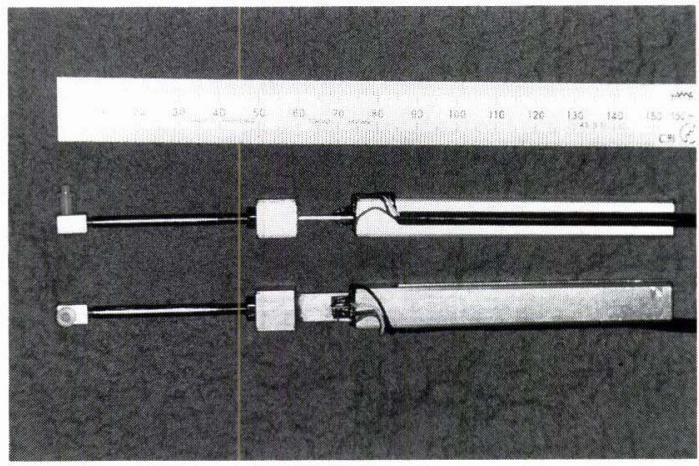

図 12 試作装置 4 の探触子

\section{F.S.以下である。}

試作装置 4 の精度検定については, $20 \mathrm{~g}, 50 \mathrm{~g} の$ 分銅（JIS 検定規格品）を用いて実負荷をかけ 10 回测定（デジタル指示計ピークホールド值）し， 誤差を検討した。

\section{4.人工舌による測定精度および再現性の検討}

1）人工舌モデルの作製

臨床応用のための基礎的実験としてシリコンゲ ルにて舌モデルを作製（北里サプライ製）し，口 腔粘膜硬さ測定装置による測定を行った。試料は, 健常者粘膜の測定值からフィードバックして測定 値の小さいもの（軟らかいもの）をサンプル 1 ， 測定值の大きいもの（硬いもの）をサンプル 2 と して 2 種類を作製した。図 15 は舌モデルの作製規 格を図示したものであり, 四 16 のごとくサンプル

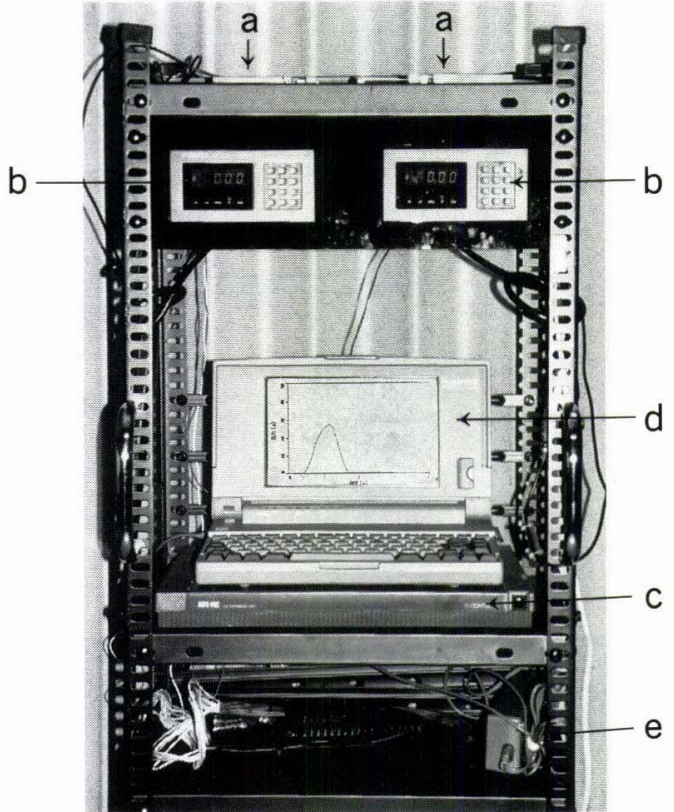
a. 探触子
b. デジタル指示計
c. $\mathrm{A} / \mathrm{D}$ 変換ボード
d. 記録用パーソナルコンピュータ
e. 移動ラック

网 13 口腔粘膜硬さ測定装置（システム） (試作装置 4)

1 はサンプル 2 よりも軟らかく，重力による変形 が著明である。上記の試料の物理的特性を明らか にするため動的粘弾性值の正確な值を, 動的粘弾

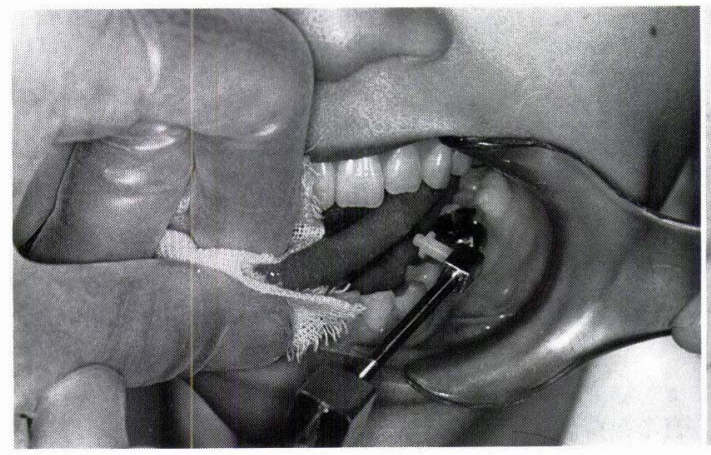

(a) 探触子非圧接時

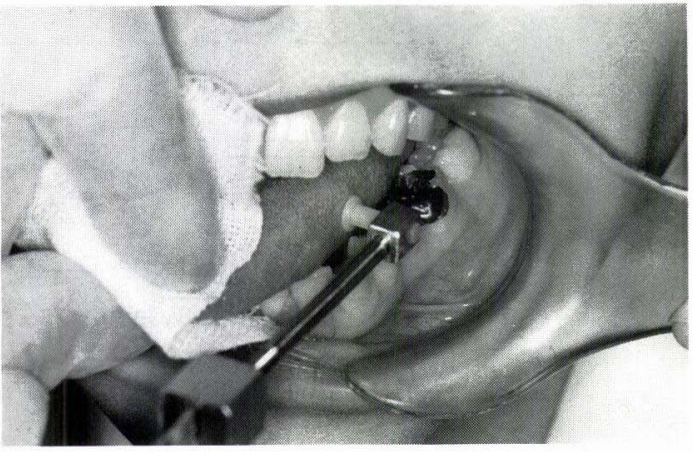

(b) 探触子圧接時

図 14 試作装置 4 による健常者舌側縁部測定 


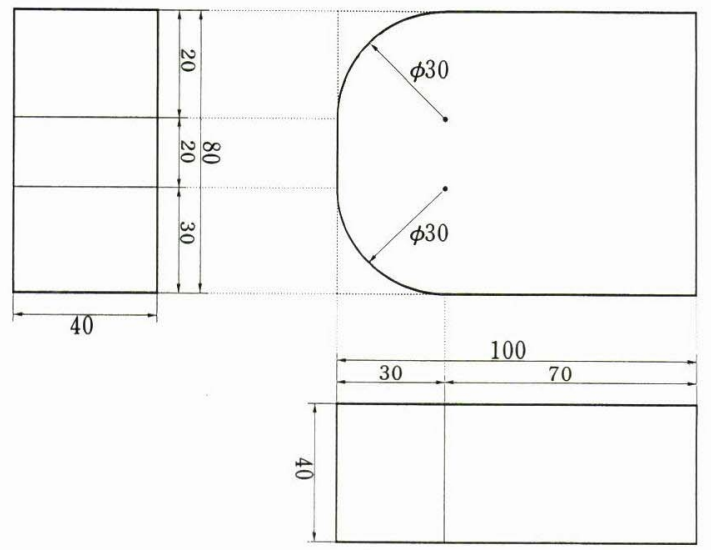

四 15 舌モデルの設計図

(サンプル 1， 2 作製规格)

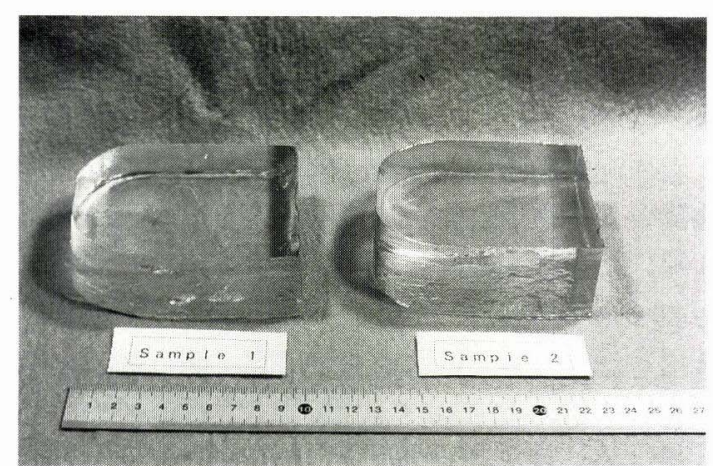

図 16 舌モデル
性測定装置 E-Plexor（理学／GABO）を使用し, 貯蔵弾性率 $\mathrm{E}$, 損失弾性率 $\mathrm{E} "$, 損失正接 $\tan \delta$ の 動的弾性率の温度依存性を調べた。

$$
(\tan \delta=\mathrm{E} " / \mathrm{E} \prime)
$$

2）人工舌モデルでの圧接速度による差

舌モデルとして作製したサンプル $1 ， 2$ の変位 一荷重関係をみるためにリニアスライド装置

(X-Y Recorder WX 4401, 渡辺計器) にて速度 を一定として図 17 に示すような直径 $2 \mathrm{~mm}$, 長さ $7 \mathrm{~mm}$ の探触子を使用しサンプルの側縁中央部を 測定した。サンプル 1,2 ともに $5,10,20 \mathrm{~mm} /$ $\mathrm{s}$ の 3 種類の速度で測定した。

3）フリーハンドによる操作

四 18 に示すようにサンプル 1 および 2 の硬さ を試作装置 4 を用いて 5 回圧接してデー夕を取 り，平均と標準偏差により測定精度を検討した。 また，当科の教室員 3 名がサンプル 1 および 2 の 硬さを試作装置 4 を用いて 5 回圧接したデー夕を 取り, 平均と標準偏差により測定精度を検討した。

\section{5. 口腔内測定方法の検討}

測定時は，被験者に力を入れないよう指示して 施行した。

1）測定部位による検討

(1) 舌粘膜の測定

健常者 2 名の舌の測定部位は第一大白歯相当部 側縁の最大豊隆部とした。舌尖を綿が一ゼを介し て，指で軽く把持し，下顎中切歯切縁の位置から

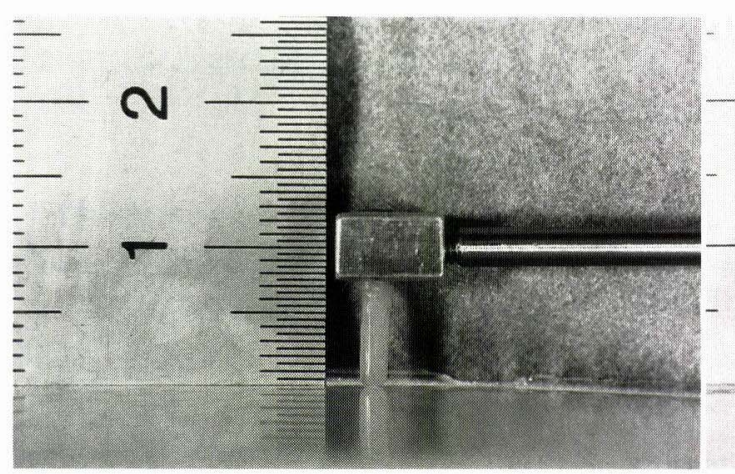

(a) 探触子非圧接時

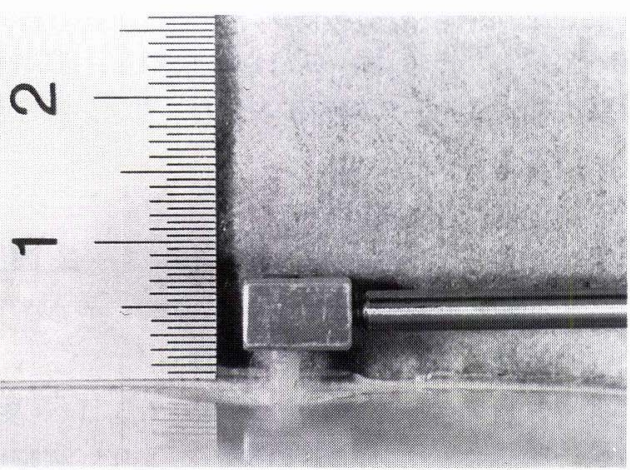

（b）探触子圧接時

困 17 サンプル測定探触子 $(7 \mathrm{~mm})$ 


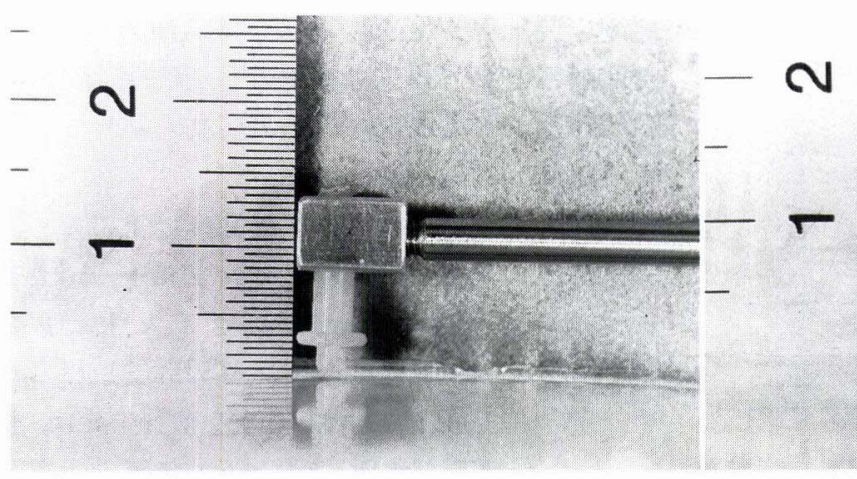

(a) 探触子非圧接時

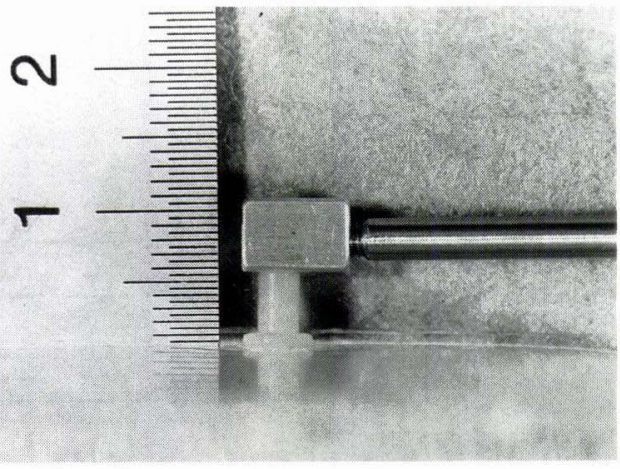

(b) 探触子圧接時

図 18 可動部粘膜硬さ測定装置による圧接練習

$0 ， 10 ， 15 ， 20 ， 25 ， 30 ， 35 ， 40 \mathrm{~mm}$ 伸展させ， 各 5 回測定し平均して算出した。なお，口角鈎を 使用し，開口度は中切歯間で $30 \sim 40 \mathrm{~mm}$ とした。

\section{(2) 頓粘膜の测定}

健常者 2 名の煩粘膜測定に際して, 中切歯間で 約 20，25，30，35，40，45 mm 開口し，上下顎第 一大臼歯相当部中央を各 5 回測定し平均して算出 した。なお，反対側に口角鈎を軽く添えて使用し た。

（3）口底粘膜の測定

健常者 3 名の舌を軽く反対側斜め後方に圧排 し, 舌下小丘の約 $10 \mathrm{~mm}$ 後方を 5 回測定し平均 して算出した。なお, 口角鈎を使用し, 開口度は 中切歯間で約 $30 \sim 40 \mathrm{~mm}$ とした。

\section{6. 同一被験者での再現性}

舌尖を下顎中切歯切縁から $20 \mathrm{~mm}$ 伸展させた 位置で測定した。なお, 口角鈎を使用し, 開口度 は中切歯間で約 30〜 $40 \mathrm{~mm}$ とした。以下, 舌の測 定は本測定条件に従った。

1）測定回数の検討

健常者 2 名の舌を $1 \sim 5,1 \sim 10,1 \sim 20$ 回測 定し, 平均値と標準偏差を示した。

2) 測定值の再現性に関する検討

健常者 2 名の舌を各 5 回 1 日間隔で 3 日 ( 3 度) にわたって測定し, 測定日の違いにより, 測定值 が変化するか否か検討した。

\section{7. 測定者が異なった場合の再現性}

当科教室員 3 名が健常被験者 2 名を各 5 回測定 し測定者間に差異があるか否かを検討した。

\section{8. 健常者口腔粘膜の硬さ}

以上の測定方法の結果より以下のような測定方 法を採用した。

舌の測定部位は第一大臼歯相当部側縁の最大豊 隆部とし，測定条件としては舌尖を綿がーゼを介 して，指で軽く把持し，下顎中切歯切縁の位置か ら $20 \mathrm{~mm}$ 以内に伸展させ各 5 回測定し平均して 算出した。なお，口角鈎を使用し，開口度は中切 歯間で約 $30 \sim 40 \mathrm{~mm}$ とした。

頼粘膜では中切歯間で約 $25 \mathrm{~mm}$ 開ロし，上下 顎第一大鼠歯を結んだほぼ中点を測定した。なお， 口角鈎を反対側に軽く添えて使用した。

口底では，舌を斜め後方に圧排し，舌下小丘の 約 $10 \mathrm{~mm}$ 後方を 5 回測定し平均して算出した。 なお, 口角鈎を使用し, 開口度は中切歯間で約 30〜 40 mm とした。

\section{9. 病変の測定}

病変部位による測定条件は，8.の健常粘膜と同 様とし病変の中心部と思われる任意の 5 筒所を測 定し平均值で表した。また病変のコントロールは, 健康と思われる病変の前方, または後方を 5 回測 定して平均して算出し対照（コントロール）とし た。しかし, 病変が大きい場合は, 病変測定部位 に相当する反対側同部位を 5 回測定し平均して算 出した。 


\section{IV. 結果}

\section{1. 測定機の比較}

1）試作装置 1

測定值は，ほぼ同一の部位を 10 回測定し，平均 して算出した。その結果, ロードセルとUずみゲー ジともに, 健常者 5 例の舌側縁では $11.3 \sim 18.3 \mathrm{gf}$ の值が得られ，変位と荷重の関係で硬さを定量的 に表現することが可能であると考えられた。しか し, 舌扁平上皮癌 2 例のうち 1 例は, $98.0 \mathrm{gf}$ で あったが，もう 1 例は $2 \mathrm{~mm}$ までの変位は得られ ず，測定できなかった。また，污染防止カバー(菲 薄ラテックス）による誤差は不明であった。

2) 試作装置 2

健常者 5 例の舌側縁では, $8.77 \sim 12.18 \mathrm{gf}$, 舌扁 平上皮癌 1 例を 10 回測定したところ $15.2 \sim 38.6$ gf（平均 $25.1 \mathrm{gf} \pm 8.7 \mathrm{gf}$ ） と測定值にばらつきが みられた。唾液の污染防止カバーの介在が試作装 置 1 よりも大きく影響していると思われた。

3) 試作装置 3

スプリングの強さを $10 \mathrm{gf}$ として測定した結 果，健常者の舌側縁で，3.5 8.3 gf だった。舌扁 平上皮癌では, 測定值が正常粘膜より大きくただ ちに探触子可動部のフルストローク $(3.5 \mathrm{~mm})$ を 圧接したため正確に測定されなかった。弾性率の 小さなスプリングではその強さがデー夕に反映す るため，弾性率の高いスプリング (50 gf まで) の 使用も試みたが，事実上測定は困難であった。ま た，使用後の分解清掃が煩雑なことや探触子の重 さが $20 \mathrm{~g}$ 以上，厚みが $20 \mathrm{~mm}$ あるため口腔内で の実際の使用に適さないと判断された。

\section{4) 試作装置 4}

健常者 5 例の舌側縁の測定結果は各 3.94 5. $88 \mathrm{gf}$ であり, 舌扁平上皮癌 2 例では $31.05,40.06$ gf であり，健常粘膜および口腔癌の測定が可能で あると推察された。以下の実験ならびに実際の計 測は，本試作装置 4 （口腔粘膜硬さ測定装置）を 使用した。

\section{2. 探触子の大きさの検討}

探触子の直径と変位量が舌粘膜に圧痕を残遺す

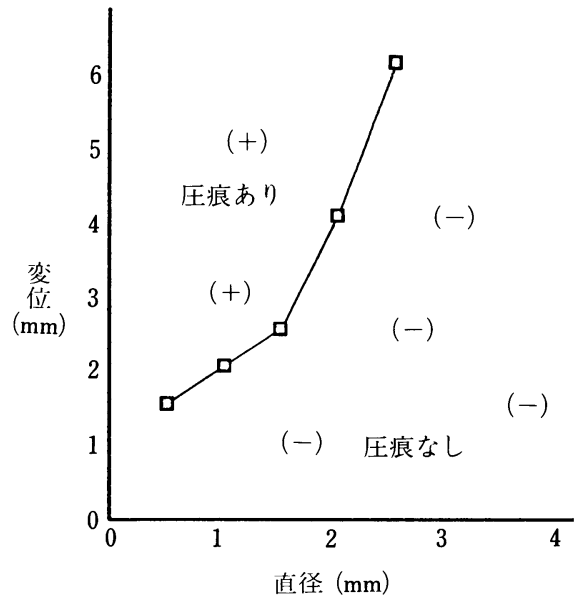

図 19 探触子直径，変位と圧痕残遺

る様相を肉眼的に調べてみたのが図 19 であり, 健 常者 5 名を対象とした。その結果, 探触子直径が $3 \mathrm{~mm}$ では，変位の奉用域と仮定している変位 6 $\mathrm{mm}$ でも圧痕が残らず，直径 $2.5 \mathrm{~mm}$ では，変位 $6 \mathrm{~mm}$ で圧痕を認める例がみられ，直径 2.0，1.5, $1.0 ， 0.5 \mathrm{~mm}$ では，それぞれ変位 $4.0 ， 2.5 ， 2.0$, $1.5 \mathrm{~mm}$ にて圧痕残遺がみられる例があった。

\section{3. 測定装置の精度}

試作装置 4 により, $20 \mathrm{~g}$ と $50 \mathrm{~g}$ の分銅を用いて 各 10 回測定したところ, $20 \mathrm{~g}$ の分銅の測定平均 值は $19.99 \mathrm{gf}$, 標準偏差は $0.02 \mathrm{gf}$ であった。測定 の誤差は $0.01 \mathrm{gf} \pm 0.02 \mathrm{gf}$ (測定重量に対し 0 . $05 \pm 0.10 \%$ ）であった。 $50 \mathrm{~g}$ の分銅では，測定平 均値 $50.00 \mathrm{gf}$, 標準偏差 $0.04 \mathrm{gf}$ で, 測定後差は 0 . $00 \mathrm{gf} \pm 0.04 \mathrm{gf}$ (測定重量に対し $0.00 \pm 0.08 \%$ )で あった。

\section{4. 人エ舌モデルによる測定精度および再現性の 検討}

1）人工舌モデルの物性

図 20 は温度変化に伴う弾性率の変化を示した もので，サンプル 1 では $0 \sim 50^{\circ} \mathrm{C}$ において貯蔵弾 性率は変化を認めず，損失弾性率も実用測定温度 15 $25^{\circ} \mathrm{C}$ においてほぼ安定しており，サンプル 2 においても同様の結果であった。なお， $36.7^{\circ} \mathrm{C} の$ 貯蔵弾性率は軟らかいサンプル 1 で $9.4 \times 10^{3} \mathrm{~Pa}$ $\left(=96 \mathrm{gf} / \mathrm{cm}^{2}\right)$, 硬いサンプル 2 では $3.8 \times 10^{4} \mathrm{~Pa}$ 
$\left(=388 \mathrm{gf} / \mathrm{cm}^{2}\right)$ であり, 弾性率がおよそ 4 倍異 なっていた。

2) 人工舌モデルの圧接速度別測定結果

測定の結果両サンプルとも測定速度が速くなる につれ測定值が大きくなることが確かめられた

(図 21)。サンプル別に $2 \mathrm{~mm}$ 変位した位置の荷 重をみると, サンプル 1 では速度 $5,10,20 \mathrm{~mm} /$
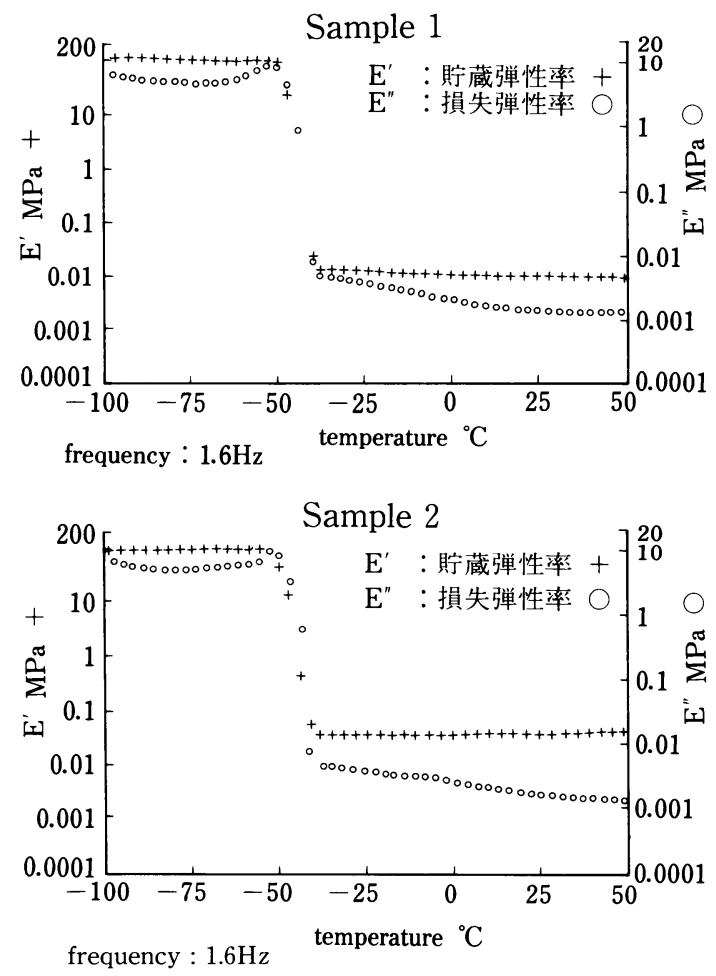

図 20 舌モデル温度依存性（E-plexor）

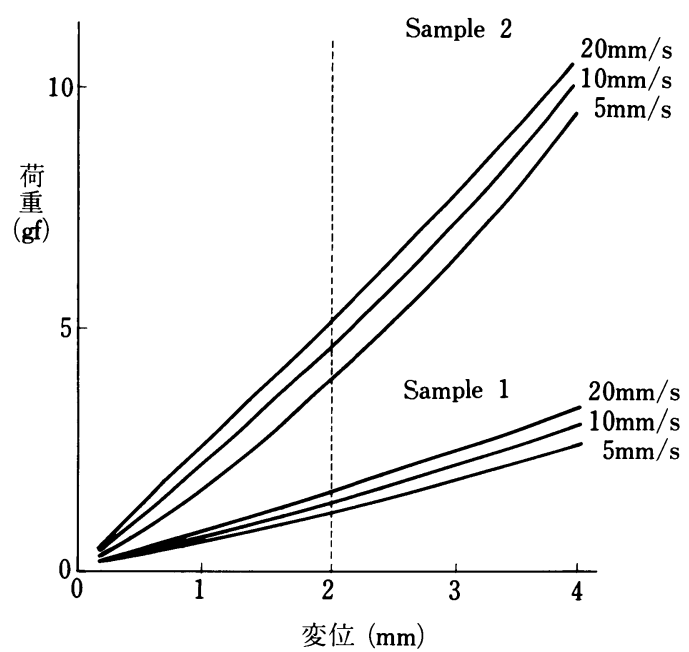

図 21 圧接速度別荷重一変位曲線

$\mathrm{s}$ にて，1.25，1.40, $1.63 \mathrm{gf}$ であり，サンプル 2 では同様に各々 $3.88,4.59,5.13 \mathrm{gf}$ であった。サ ンプル別に $2 \mathrm{~mm}$ 変位時の圧接速度の増加と荷 重の関係をみると，サンプル 1 では圧接速度 2 倍 時の荷重増加はそれぞれ $0.15,0.23 \mathrm{gf}$ となり増 加率は各 $12.0,16.4 \%$ であり，サンプル 2 でも同 様に圧接速度 2 倍時の荷重の増加がそれぞれ 0 . $71,0.54 \mathrm{gf}$ となり増加率は $18.3,11.8 \%$ であっ た。よって，同一サンプルでは，圧接速度が 2 倍 になっても荷重は $18 \%$ 程度の増加に留まり, 変位 量が等しければ測定値は大きく異ならないと考え られた。

続いて各圧接速度別に変位 $2 \mathrm{~mm} \pm 0.2 \mathrm{~mm}$ （土10\%）の荷重から変位量の影響をみることと

表 2 舌モデルの圧接速度別測定值 $2 \mathrm{~mm} \pm 0.2 \mathrm{~mm}( \pm 10 \%)$

\begin{tabular}{|c|c|c|c|c|c|c|}
\hline 圧接速度 $(\mathrm{mm} / \mathrm{s})$ & \multicolumn{3}{|c|}{ サンプル 1} & \multicolumn{3}{|c|}{ サンプル 2} \\
\hline 変位 & 5 & 10 & 20 & 5 & 10 & 20 \\
\hline $1.8 \mathrm{~mm}$ & 1.13 & 1.28 & 1.44 & 3.38 & 4.06 & 4.59 \\
\hline 差(\%) & $0.12(9.6)$ & $0.12(8.6)$ & $0.19(11.7)$ & $0.50(12.9)$ & $0.53(11.5)$ & $0.46(9.0)$ \\
\hline $2.0 \mathrm{~mm}$ & 1.25 & 1.40 & 1.63 & 3.88 & 4.59 & 5.13 \\
\hline 差(\%) & $0.13(10.4)$ & $0.16(11.4)$ & $0.18(11.0)$ & $0.50(12.9)$ & $0.46(10.0)$ & $0.50(9.7)$ \\
\hline $2.2 \mathrm{~mm}$ & 1.38 & 1.56 & 1.81 & 4.38 & 5.13 & 5.63 \\
\hline
\end{tabular}

単位：gf, 各 5 回測定 標準偏差 $\leqq 0.01 \mathrm{gf}$ 
した。表 2 に各サンプルの圧接速度別に各 $1.8,2$. $0,2.2 \mathrm{~mm}$ 変位時の荷重と各々の差およびその百 分率を示した。サンプル 1 においては, $5 \mathrm{~mm} / \mathrm{s}$ の荷重の差はそれぞれ $0.12 \mathrm{gf}(9.6 \%), 0.13 \mathrm{gf}$ (10.4\%), $10 \mathrm{~mm} / \mathrm{s}$ は $0.12 \mathrm{gf}(8.6 \%), 0.16 \mathrm{gf}$ (11.4\%), $20 \mathrm{~mm} / \mathrm{s}$ は $0.19 \mathrm{gf}(11.7 \%), 0.18 \mathrm{gf}$ (11.0\%) であり，誤差は 8.6〜11.7\%であった。 サンプル 2 においては, $5 \mathrm{~mm} / \mathrm{s}$ の荷重の差は 0 . $50 \mathrm{gf}(12.9 \%), 0.50 \mathrm{gf}(12.9 \%), 10 \mathrm{~mm} / \mathrm{s}$ は 0 . $53 \mathrm{gf}(11.5 \%), 0.46 \mathrm{gf}(10.0 \%), 20 \mathrm{~mm} / \mathrm{s}$ は 0 . 46 gf (9.0\%)，0.50 gf (9.7\%) であり，誤差は 9. 0〜 $12.9 \%$ であった（表 2 )。

次に, 図 22 は, 圧接速度別の相対弾性率と変位 の関係を示したものである。圧接速度にかかわら ず変位量 $4 \mathrm{~mm}$ までの相対弾性率はほぼ一定で あった。

3）フリーハンドによる操作

3 検査者 $(\mathrm{A}, \mathrm{B}, \mathrm{C})$ による測定結果は表 3 に 示すとおりである。サンプル 1 における各検查者 の測定平均値（標準偏差）は1.42 gf (0.06 gf), $1.41 \mathrm{gf}(0.04 \mathrm{gf}), 1.44 \mathrm{gf}(0.06 \mathrm{gf})$ であった。 サンプル 2 も同様に測定平均值 (標準偏差) は 4 . $78 \mathrm{gf}(0.20 \mathrm{gf}), 4.79 \mathrm{gf}(0.15 \mathrm{gf}), 4.81 \mathrm{gf}(0.18$ gf）であった（表 3$) 。$

\section{5. 口腔内測定方法の検討}

1) 舌

下顎中切歯の位置から舌尖を $0 \sim 40 \mathrm{~mm}$ 前方 へ伸展させたことによる測定值への影響は表 4 に 示すように, 被験者 1,2 ともに測定平均値は, 舌の伸展につれて増加していた。被検者 1 で，0 $\mathrm{mm}$ の最小〜最大 (平均值士標準偏差) は, それ

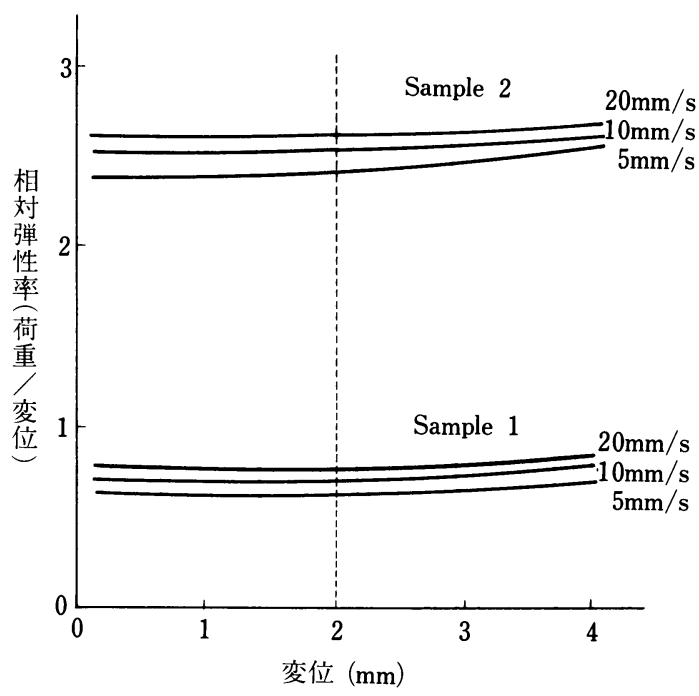

図 22 圧接速度別相対弾性率一変位曲線

ぞれ 3.82 4.34 gf( $4.07 \pm 0.11 \mathrm{gf}), 15 \mathrm{~mm}$ では, $3.85 \sim 4.48$ gf (4.12士0.17 gf), $20 \mathrm{~mm}$ では, 4 . $31 \sim 4.67 \mathrm{gf}(4.45 \pm 0.11 \mathrm{gf})$ であり, 平均値の差

( $0 \mathrm{~mm}$ 位置に比べ) は $15 \mathrm{~mm}$ までは $0.05 \mathrm{gf}$, $1.2 \%$ 以内であり, $20 \mathrm{~mm}$ 以上では $0.38 \mathrm{gf}, 9.3 \%$ 以上であった。

被験者 2 では，舌の伸展が $0 \mathrm{~mm}$ のとき，それ ぞれ 3.14 3.62 gf (3.29 0.11 gf)，15 mm では $3.26 \sim 3.73 \mathrm{gf}(3.45 \pm 0.13 \mathrm{gf}), 20 \mathrm{~mm}$ では 3 . $42 \sim 3.98 \mathrm{gf}(3.63 \pm 0.19 \mathrm{gf})$ であり, 平均值の差 $(0 \mathrm{~mm}$ 位置に比べ)は $15 \mathrm{~mm}$ までは $0.16 \mathrm{gf}, 4$. $8 \%$ 以内であり, $20 \mathrm{~mm}$ 以上では $0.34 \mathrm{gf}, 9.4 \%$ 以 上であった。

両被験者ともに $20 \mathrm{~mm}$ までは, 平均值の差が $10 \%$ 以内で，比較的小さく，実際の測定では 20

表 3 舌モデルのフリーハンドによる測定再現性

\begin{tabular}{c|ccc|ccc}
\hline \hline \multirow{2}{*}{ 検查者 } & \multicolumn{3}{|c|}{ サンプル 1} & \multicolumn{3}{c}{ サンプル 2} \\
\cline { 2 - 7 } & 最小〜最大 & 平均 & 標準偏差 & 最小〜最大 & 平均 & 標準偏差 \\
\hline $\mathrm{A}$ & $1.29 \sim 1.49$ & 1.42 & 0.06 & $4.23 \sim 5.28$ & 4.78 & 0.20 \\
$\mathrm{~B}$ & $1.35 \sim 1.46$ & 1.41 & 0.04 & $4.41 \sim 5.12$ & 4.79 & 0.15 \\
$\mathrm{C}$ & $1.31 \sim 1.51$ & 1.44 & 0.06 & $4.29 \sim 5.22$ & 4.81 & 0.18 \\
\hline
\end{tabular}

単位: gf, 各 5 回測定 
表 4 舌測定值への舌尖の位置による影響

\begin{tabular}{r|c|c}
\hline \multicolumn{1}{c|}{ 舌尖の位置 } & $\begin{array}{c}\text { 被験者 } 1 \\
\text { 最小値 最大值 }(\text { 平均值 } \pm \mathrm{SD})\end{array}$ & $\begin{array}{c}\text { 被験者 } 2 \\
\text { 最小值 最大值 }(\text { 平均值 } \pm \mathrm{SD})\end{array}$ \\
\hline 下顎中切歯より $0 \mathrm{~mm}$ 前方 & $3.82 \sim 4.34(4.07 \pm 0.11)$ & $3.14 \sim 3.62(3.29 \pm 0.11)$ \\
\hline $10 \mathrm{~mm}$ 前方 & $3.85 \sim 4.44(4.09 \pm 0.12)$ & $3.19 \sim 3.69(3.33 \pm 0.12)$ \\
\hline $15 \mathrm{~mm}$ 前方 & $3.85 \sim 4.48(4.12 \pm 0.17)$ & $3.26 \sim 3.73(3.45 \pm 0.13)$ \\
\hline $20 \mathrm{~mm}$ 前方 & $4.31 \sim 4.67(4.45 \pm 0.11)$ & $3.42 \sim 3.98(3.63 \pm 0.19)$ \\
\hline $25 \mathrm{~mm}$ 前方 & $4.41 \sim 4.73(4.58 \pm 0.11)$ & $3.38 \sim 4.56(3.97 \pm 0.32)$ \\
\hline $30 \mathrm{~mm}$ 前方 & $4.51 \sim 5.41(5.10 \pm 0.21)$ & $4.07 \sim 4.78(4.42 \pm 0.17)$ \\
\hline $35 \mathrm{~mm}$ 前方 & $4.72 \sim 5.46(5.18 \pm 0.21)$ & $4.32 \sim 5.18(4.72 \pm 0.17)$ \\
\hline $40 \mathrm{~mm}$ 前方 & $5.18 \sim 5.97(5.50 \pm 0.29)$ & $4.81 \sim 5.97(5.26 \pm 0.41)$ \\
\hline
\end{tabular}

単位：gf, 各 5 回測定

$\mathrm{mm}$ 以内で測定するのがよいと考えられた。

\section{2) 頓粘膜}

健常者 2 名で, 中切歯間で $20,25 ， 30 ， 35 ， 40$, $45 \mathrm{~mm}$ 開口し, 上下顎第一大臼歯相当部の中央を 測定した結果，被験者 1 では開口域 20，25，30， $35,40,45 \mathrm{~mm}$ では各 $1.53 \pm 0.19 \mathrm{gf}, 1.61 \pm 0.20$ gf, $2.55 \pm 0.12$ gf, $3.73 \pm 0.12$ gf, $4.14 \pm 0.21$ gf, $4.85 \pm 0.23 \mathrm{gf}$ と開口域に応じて測定平均值も増 加していた。開口度 $20 \mathrm{~mm}$ を基準とした時の測 定平均值の差は $25 \mathrm{~mm}$ では $0.08 \mathrm{gf}, 5.2 \%$ であ $\eta, 30 \mathrm{~mm}$ 以上では $1.02 \mathrm{gf}, 66.7 \%$ 以上であっ た。被験者 2 においても同様に開口域 $20,25,30$,
$35,40,45 \mathrm{~mm}$ では各 $2.60 \pm 0.11 \mathrm{gf}, 2.81 \pm 0.18$ gf, $3.60 \pm 0.20 \mathrm{gf}, 4.05 \pm 0.11 \mathrm{gf}, 4.81 \pm 0.22 \mathrm{gf}$, $5.45 \pm 0.18 \mathrm{gf}$ であった。開口度 $20 \mathrm{~mm}$ を基準と した時の測定平均值の差は $25 \mathrm{~mm}$ では $0.21 \mathrm{gf}$, $7.5 \%$ であり，30 mm 以上では $1.00 \mathrm{gf}, 38.5 \%$ 以 上であった。両被験者ともに $20 \sim 25 \mathrm{~mm}$ ではほ ぼ一定の值が得られ, 開口度 $20 \sim 25 \mathrm{~mm}$ で測定 するのがよいと考えられた（表 5 )。

3）口底

健常者 3 名を測定した結果, 被験者 1 では, 平 均值士標準偏差は $4.29 \pm 0.29 \mathrm{gf}$ で, 被験者 2 で は, $4.53 \pm 0.19 \mathrm{gf}$ であり, 被験者 3 では, $2.85 \pm$

表 5 頓粘膜測定値への開口域の影響

\begin{tabular}{c|c|c}
\hline \hline 開口域 & $\begin{array}{c}\text { 被験者 } 1 \\
\text { 最小值～最大值 }(\text { 平均值 } \pm \mathrm{SD})\end{array}$ & $\begin{array}{c}\text { 被験者 } 2 \\
\text { 最小值～最大值 }(\text { 平均值 } \pm \mathrm{SD})\end{array}$ \\
\hline $20 \mathrm{~mm}$ & $1.23 \sim 1.80(1.53 \pm 0.19)$ & $2.37 \sim 2.80(2.60 \pm 0.11)$ \\
\hline $25 \mathrm{~mm}$ & $1.32 \sim 1.95(1.61 \pm 0.20)$ & $2.52 \sim 3.06(2.81 \pm 0.18)$ \\
\hline $30 \mathrm{~mm}$ & $2.39 \sim 2.72(2.55 \pm 0.12)$ & $3.37 \sim 3.97(3.60 \pm 0.20)$ \\
\hline $35 \mathrm{~mm}$ & $3.59 \sim 3.98(3.73 \pm 0.12)$ & $3.88 \sim 4.19(4.05 \pm 0.11)$ \\
\hline $40 \mathrm{~mm}$ & $3.77 \sim 4.44(4.14 \pm 0.21)$ & $4.52 \sim 5.08(4.81 \pm 0.22)$ \\
\hline $45 \mathrm{~mm}$ & $4.52 \sim 5.04(4.85 \pm 0.23)$ & $5.27 \sim 5.84(5.45 \pm 0.18)$ \\
\hline
\end{tabular}

単位：gf, 各 5 回測定 
0.22 gf であり一定した測定値が得られた。

\section{6. 同一被験者での再現性}

1) 測定回数の検討

健常者 2 名の舌を 20 回測定し $1 \sim 5,1 \sim 10$, $1 \sim 20$ 回の測定值の平均值と標準偏差を比較す ると，被験者 1 では，それぞれ $4.22 \pm 0.13 \mathrm{gf}, 4$. $21 \pm 0.12$ gf, $4.22 \pm 0.10$ gf で, 被験者 2 では, 4. $34 \pm 0.14$ gf, $4.33 \pm 0.12$ gf, $4.33 \pm 0.09$ gf であっ た。いずれも測定回数が増えると標準偏差は，わ ずかに減少するものの, 平均値に差はなかったこ とから測定回数を 5 回とし，平均值で示すことと した (表 6 )。

表 6 测定回数の検討

\begin{tabular}{c|c|c}
\hline \hline 測定回数 & $\begin{array}{c}\text { 被験者 } 1 \\
\text { 平均值 } \pm \mathrm{SD}\end{array}$ & $\begin{array}{c}\text { 被験者 } 2 \\
\text { 平均值 } \pm \mathrm{SD}\end{array}$ \\
\hline $1 \sim 5$ & $4.22 \pm 0.13$ & $4.34 \pm 0.14$ \\
$1 \sim 10$ & $4.21 \pm 0.12$ & $4.33 \pm 0.12$ \\
$1 \sim 20$ & $4.22 \pm 0.10$ & $4.33 \pm 0.09$ \\
\hline 平均值の差 & 0.01 & 0.01 \\
\hline
\end{tabular}

単位：gf, 各 5 回測定

2）測定值の再現性に関する検討

健常者 2 名の舌を各 5 回， 1 日間隔で計 3 度に わたって測定し 3 度のそれぞれの平均值を比較 し，再現性を検討した。被験者 1 では，1度目の 平均值は $3.43,2$ 度目 : $3.38,3$ 度目 $: 3.51 \mathrm{gf}$
で， 3 度の全平均値は $3.44 \mathrm{gf}$, 平均值の差は最大 $0.13 \mathrm{gf}$, 最大誤差は $3.8 \%$ であった。被験者 2 で は， $1 \sim 3$ 度目の平均值は各々 $3.53,3.48,3.42$ $\mathrm{gf}, 3$ 度の平均值は $3.48 \mathrm{gf}$, 平均值の最大差は 0 . $11 \mathrm{gf}$, 最大誤差 $3.2 \%$ であった。以上より最大誤差 は 5\%以下であり再現性が優れていると判断され た (表 7 )。

\section{7. 測定者が異なった場合の再現性}

健常者 2 名の舌の同一部位を当科教室員 3 名が 各 5 回測定した結果, 被験者 1 では, 各測定者の 平均值は各々 $3.43,3.52,3.56 \mathrm{gf}, 3$ 者の平均值 は $3.50 \mathrm{gf}$, 平均值の差は最大 $0.13 \mathrm{gf}$, 最大誤差 $3.7 \%$, 被験者 2 では, 各検查者の平均值は各々 3.

表 7 被験者 2 名による舌測定値の再現性 -1 日間隔 3 度測定一

\begin{tabular}{c|c|c}
\hline \hline 測 定 回 & $\begin{array}{c}\text { 被 験 者 1 } \\
\text { 平均值 } \pm \mathrm{SD}\end{array}$ & $\begin{array}{c}\text { 被 験 者 } 2 \\
\text { 平均值 } \pm \mathrm{SD}\end{array}$ \\
\hline 1 日目 & $3.43 \pm 0.19$ & $3.53 \pm 0.23$ \\
\hline 2 日目 & $3.38 \pm 0.23$ & $3.48 \pm 0.34$ \\
\hline 3 日目 & $3.51 \pm 0.18$ & $3.42 \pm 0.22$ \\
\hline 平均值 & 3.44 & 3.48 \\
\hline 平均值の最大差 & 0.13 & 0.11 \\
\hline 最大誤差 & $3.8 \%$ & $3.2 \%$ \\
\hline
\end{tabular}

単位：gf，各 5 回測定

表 8 測定者 3 名による舌測定值の再現性

\begin{tabular}{c|c|c}
\hline \hline 検査者 & $\begin{array}{c}\text { 被験者 } 1 \\
\text { 最小值～最大值 }(\text { 平均值 } \pm \mathrm{SD})\end{array}$ & $\begin{array}{c}\text { 被験者 } 2 \\
\text { 最小值～最大值 }(\text { 平均值 } \pm \mathrm{SD})\end{array}$ \\
\hline 1 & $3.18 \sim 3.67(3.43 \pm 0.14)$ & $3.23 \sim 3.83(3.53 \pm 0.18)$ \\
\hline 2 & $3.33 \sim 3.93(3.52 \pm 0.22)$ & $3.38 \sim 3.92(3.56 \pm 0.14)$ \\
\hline 3 & $3.22 \sim 3.84(3.56 \pm 0.23)$ & $3.32 \sim 3.93(3.63 \pm 0.21)$ \\
\hline 平均值 & 3.50 & 3.57 \\
\hline 平均值の最大差 & 0.13 & 0.10 \\
\hline 最大誤差 & $3.7 \%$ & $2.8 \%$ \\
\hline
\end{tabular}

単位：gf, 各 5 回測定 
$53,3.56,3.63 \mathrm{gf}, 3$ 検者の平均值は $3.57 \mathrm{gf}$, 平 均值の最大差 $0.10 \mathrm{gf}$ で, 最大誤差 $2.8 \%$ であっ た。以上より最大䛊差は $5 \%$ 以下であり再現性が 優れていると判断された（表 8 )。

\section{8. 健常粘膜の硬さ}

表 9 に示すように，舌ならびに煩粘膜は全例測 定可能であったが，口底の 8 例では，口底部が深 く, 粘膜面までの距離が大きすぎて測定不能で あった。硬さ測定值は, 舌では, 最小 $2.39 \mathrm{gf}$, 最 大 $6.78 \mathrm{gf}$ で平均 $4.45 \mathrm{gf}$ (標準偏差 $1.16 \mathrm{gf}$ ), 口 底では最小 $2.00 \mathrm{gf}$, 最大 $6.26 \mathrm{gf}$, 平均 $4.33 \mathrm{gf}$ (標

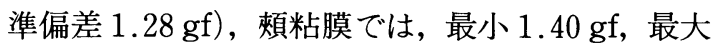
$5.27 \mathrm{gf}$, 平均 $2.96 \mathrm{gf}$ （標準偏差 $0.80 \mathrm{gf）であっ}$ た。探触子先端に付けられた丸みは軽微なのでこ れを無視して探触子の断面積を求め, これから単 位面積あたりの硬さの平均値を表すと表 9 最下段 に示すように舌は $141.6 \mathrm{gf} / \mathrm{cm}^{2}\left(1.39 \times 10^{4} \mathrm{~Pa}\right)$, 口底は $137.8 \mathrm{gf} / \mathrm{cm}^{2}\left(1.35 \times 10^{4} \mathrm{~Pa}\right)$, 煩粘膜は $94.2 \mathrm{gf} / \mathrm{cm}^{2}\left(9.23 \times 10^{3} \mathrm{~Pa}\right)$ であった。なお, $1 \mathrm{gf} /$ $\mathrm{cm}^{2}=98 \mathrm{~Pa}$ で換算した。部位での比較すると, 舌 が最も硬く, 次いで口底, 煩粘膜の順であった。 なお，舌と頓粘膜間および口底と頓粘膜の硬さ測 定值は, 推計学的 ( $\mathrm{t}$ 検定, Wilcoxon 検定) に有 意差を認めた $(\mathrm{p}<0.001)$ 。しかし舌と口底では有 意差はみられなかった。

\section{9. 口腔粘膜疾患の硬さ}

1）扁平上皮癌の硬さ

(1) 舌癌

舌癌 20 例の硬さ測定值は $16.87 \sim 80.32 \mathrm{gf}$, 平 均 $34.83 \mathrm{gf}$ (標準偏差 $17.22 \mathrm{gf}$ ) であった。一方, 周囲の健常粘膜（コントロール）の硬さ測定值は

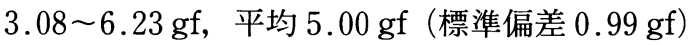
で，いずれも病変の值がコントロールを上回って いた。コントロールに対する病変の比は, 2 . $31 \sim 16.29$ 倍で平均 6.97 倍と病変が高值を示し, 推計学的 ( $\mathrm{t}$ 検定, Wilcoxon 検定) に有意差を認 めた $(\mathrm{p}<0.001)$ 。病変とコントロールの平均值の 単位面積あたりの硬さ測定值はそれぞれ 1108.7 $\mathrm{gf} / \mathrm{cm}^{2}\left(1.09 \times 10^{5} \mathrm{~Pa}\right), 159.2 \mathrm{gf} / \mathrm{cm}^{2}\left(1.56 \times 10^{4}\right.$ $\mathrm{Pa}$ )であった（表 $10 \mathrm{~A} ） 。$
表 9 健常者粘膜の硬さ測定値

\begin{tabular}{|c|c|c|c|c|}
\hline No. & 年齢 性 & 舌 & 口底 & 煩粘膜 \\
\hline 1 & $24 \quad \mathrm{~N}$ & 6.78 & 5.25 & 2.95 \\
\hline 2 & 24 & 3.94 & 3.16 & 2.68 \\
\hline 3 & 25 & 3.43 & 4.29 & 3.94 \\
\hline 4 & 26 & 4.85 & 5.30 & 2.48 \\
\hline 5 & 29 & 3.15 & 2.63 & 3.70 \\
\hline 6 & 33 & 4.81 & 4.53 & 3.64 \\
\hline 7 & 34 & 5.62 & 5.70 & 3.25 \\
\hline 8 & 36 & 5.50 & 6.10 & 1.57 \\
\hline 9 & 38 & 2.39 & 2.85 & 2.33 \\
\hline 10 & 48 & 2.43 & 2.77 & 2.77 \\
\hline 11 & 24 & 3.60 & 5.10 & 2.68 \\
\hline 12 & 25 & 3.96 & 4.46 & 2.87 \\
\hline 13 & 25 & 3.19 & 2.00 & 1.40 \\
\hline 14 & 26 & 3.23 & 3.74 & 3.03 \\
\hline 15 & 27 & 6.18 & 4.89 & 2.56 \\
\hline 16 & 29 & 5.53 & 4.46 & 2.69 \\
\hline 17 & 42 & 5.62 & 6.26 & 4.16 \\
\hline 18 & 25 & 4.12 & - & 2.72 \\
\hline 19 & 25 & 3.66 & - & 5.27 \\
\hline 20 & 28 & 5.09 & - & 2.39 \\
\hline 21 & 40 & 5.88 & - & 2.85 \\
\hline 22 & 25 & 4.21 & - & 3.76 \\
\hline 23 & 26 & 4.63 & - & 2.75 \\
\hline 24 & 26 & 4.77 & - & 2.69 \\
\hline 25 & 28 & 4.78 & - & 2.89 \\
\hline \multicolumn{2}{|c|}{ 平 均 $(\mathrm{gf})$} & 4.45 & 4.33 & 2.96 \\
\hline \multicolumn{2}{|c|}{ 標準偏差 (gf) } & 1.16 & 1.28 & 0.80 \\
\hline \multirow{2}{*}{\multicolumn{2}{|c|}{$\begin{array}{c}\text { 平均 }\left(\mathrm{gf} / \mathrm{cm}^{2}\right) \\
(\mathrm{Pa})\end{array}$}} & 141.6 & 137.8 & 94.2 \\
\hline & & $1.39 \times 10^{4}$ & $1.35 \times 10^{4}$ & $9.23 \times 10^{3}$ \\
\hline
\end{tabular}

(2) 口底癌

口底癌 3 例の硬さ測定值は $32.47 \sim 75.88 \mathrm{gf}$, 平

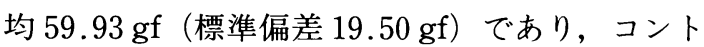
ロールは 5.07 6.34 gf, 平均 5.71 gf（標準偏差 $0.52 \mathrm{gf})$ で，いずれも病変の硬さ測定值がコント ロールよりも大きく，コントロールに対する病変 の比は，5.12 14.96 倍 (平均 10.50 倍) で例数が 少ないものの病変のほうが硬い傾向であった。病 変とコントロールの平均值の単位面積あたりの硬 
表 $10 \mathrm{~A}$ 舌扁平上皮癌の硬さ測定值

\begin{tabular}{|c|c|c|c|c|c|c|c|c|}
\hline \multirow{2}{*}{ No. } & \multirow{2}{*}{ 年齢 } & \multirow{2}{*}{ 性 } & \multirow{2}{*}{ 部位 } & \multirow{2}{*}{$\begin{array}{c}\text { 最大径 } \\
(\mathrm{mm})\end{array}$} & \multirow{2}{*}{$\begin{array}{c}\text { 臨床 } \\
\text { 視診型 }\end{array}$} & \multicolumn{2}{|c|}{ 硬さ測定值 (gf) } & \multirow{2}{*}{ 硬さの比：L/C } \\
\hline & & & & & & LESION & CONTROL & \\
\hline 1 & 31 & M & 舌 & 37 & 肉芽 & 40.06 & 5.84 & 6.86 \\
\hline 2 & 42 & M & 舌 & 12 & 潰瘍 & 37.23 & 4.05 & 9.19 \\
\hline 3 & 47 & $\mathrm{M}$ & 舌 & 22 & びらん & 31.05 & 3.08 & 10.08 \\
\hline 4 & 49 & $\mathrm{M}$ & 舌 & 20 & 白板 & 31.00 & 5.75 & 5.39 \\
\hline 5 & 49 & $\mathrm{M}$ & 舌 & 45 & 潰痬 & 50.07 & 3.86 & 12.97 \\
\hline 6 & 53 & M & 舌 & 38 & 膨隆 & 80.32 & 4.93 & 16.29 \\
\hline 7 & 60 & M & 舌 & 13 & びらん & 23.14 & 4.53 & 5.11 \\
\hline 8 & 63 & M & 舌 & 16 & 潰瘍 & 35.12 & 6.10 & 5.75 \\
\hline 9 & 64 & M & 舌 & 15 & 潰瘍 & 38.45 & 4.45 & 8.64 \\
\hline 10 & 65 & M & 舌 & 27 & 肉芽 & 74.40 & 6.23 & 11.94 \\
\hline 11 & 65 & M & 舌 & 24 & 肉芽 & 22.81 & 5.67 & 4.02 \\
\hline 12 & 70 & M & 舌 & 19 & 潰瘍 & 20.70 & 3.60 & 5.75 \\
\hline 13 & 35 & $\mathrm{~F}$ & 舌 & 10 & 潰瘍 & 33.30 & 6.21 & 5.36 \\
\hline 14 & 43 & $\mathrm{~F}$ & 舌 & 15 & びらん & 17.35 & 5.13 & 3.38 \\
\hline 15 & 50 & $\mathrm{~F}$ & 舌 & 9 & びらん & 13.90 & 6.00 & 2.31 \\
\hline 16 & 60 & $\mathrm{~F}$ & 舌 & 21 & 肉芽 & 25.13 & 6.11 & 4.11 \\
\hline 17 & 66 & $\mathrm{~F}$ & 舌 & 16 & びらん & 29.99 & 4.24 & 7.07 \\
\hline 18 & 69 & $\mathrm{~F}$ & 舌 & 22 & 白板 & 39.19 & 5.85 & 6.69 \\
\hline 19 & 74 & $\mathrm{~F}$ & 舌 & 16 & 潰瘍 & 16.87 & 4.74 & 3.55 \\
\hline 20 & 78 & $\mathrm{~F}$ & 舌 & 21 & 潰瘍 & 36.52 & 3.66 & 9.97 \\
\hline \multicolumn{6}{|c|}{ 平 均 } & 34.83 & 5.00 & 6.97 \\
\hline & & & & \multicolumn{2}{|c|}{ 標準偏差 } & 17.22 & 0.99 & 3.52 \\
\hline & & & & \multirow{2}{*}{\multicolumn{2}{|c|}{$\begin{array}{c}\text { 平均 }\left(\mathrm{gf} / \mathrm{cm}^{2}\right) \\
(\mathrm{Pa})\end{array}$}} & 1108.7 & 159.2 & \\
\hline & & & & & & $1.09 \times 10^{5}$ & $1.56 \times 10^{4}$ & \\
\hline
\end{tabular}

表 $10 \mathrm{~B}$ 口底扁平上皮癌の硬さ測定值

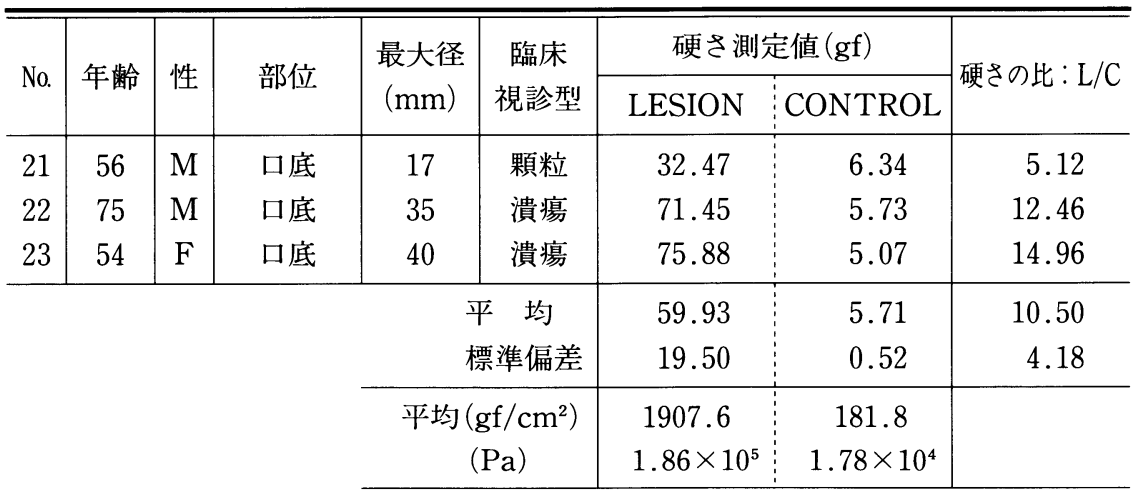


表 $10 \mathrm{C}$ 頓粘膜扁平上皮癌の硬さ測定值

\begin{tabular}{|c|c|c|c|c|c|c|c|c|}
\hline \multirow{2}{*}{ No. } & \multirow{2}{*}{ 年齿 } & \multirow{2}{*}{ 性 } & \multirow{2}{*}{ 部位 } & \multirow{2}{*}{$\begin{array}{c}\text { 最大径 } \\
(\mathrm{mm})\end{array}$} & \multirow{2}{*}{$\begin{array}{c}\text { 臨床 } \\
\text { 視診型 }\end{array}$} & \multicolumn{2}{|c|}{ 硬さ測定値 (gf) } & \multirow{2}{*}{ 硬さの比：L/C } \\
\hline & & & & & & LESION & CONTROL & \\
\hline 24 & 57 & M & 頓粘膜 & 22 & 肉芽 & 31.68 & 3.36 & 9.42 \\
\hline 25 & 60 & $\mathrm{~F}$ & 頰粘膜 & 45 & 潰瘍 & 66.93 & 3.51 & 19.06 \\
\hline 26 & 72 & $\mathrm{~F}$ & 煩粘膜 & 32 & 肉芽 & 32.02 & 5.71 & 5.60 \\
\hline \multicolumn{6}{|c|}{ 平 均 } & 43.54 & 4.19 & 10.39 \\
\hline & & & & & 16.54 & 1.07 & 5.66 \\
\hline & & & & \multirow{2}{*}{\multicolumn{2}{|c|}{$\begin{array}{c}\text { 平均 }\left(\mathrm{gf} / \mathrm{cm}^{2}\right) \\
(\mathrm{Pa})\end{array}$}} & 1385.9 & 133.4 & \\
\hline & & & & & & $1.36 \times 10^{5}$ & $1.31 \times 10^{4}$ & \\
\hline
\end{tabular}

さ測定值はそれぞれ $1907.6 \mathrm{gf} / \mathrm{cm}^{2}\left(1.86 \times 10^{5}\right.$ $\mathrm{Pa}), 181.8 \mathrm{gf} / \mathrm{cm}^{2}\left(1.78 \times 10^{4} \mathrm{~Pa}\right)$ であった（表 $10 \mathrm{~B})$ 。

\section{(3) 煩粘膜癌}

煩粘膜癌 3 例の硬さ測定值は 31.68 66.93 $\mathrm{gf}$, 平均 $43.54 \mathrm{gf}$ (標準偏差 $16.54 \mathrm{gf}$ ), コントロー ルの硬さ測定值は $3.36 \sim 5.71 \mathrm{gf}$, 平均 $4.19 \mathrm{gf}$ (標 準偏差 1.07 gf) で，いずれも病変の硬さ測定值が コントロールよりも大きく，コントロールに対す る病変の比は, $5.60 \sim 19.06$ 倍 (平均 10.39 倍) で 例数が少ないものの病変のほうが硬い傾向であっ た。病変とコントロールの平均值の単位面積あた りの硬さ測定値はそれぞれ，1385.9 gf/ $\mathrm{cm}^{2}$ (1. $\left.36 \times 10^{5} \mathrm{~Pa}\right), 133.4 \mathrm{gf} / \mathrm{cm}^{2}\left(1.31 \times 10^{4} \mathrm{~Pa}\right)$ であっ
た(表 $10 \mathrm{C}$ )。

2) 白板症

白板症 4 例の硬さ測定值は $4.55 \sim 8.77 \mathrm{gf}$, 平均 7.10 gf (標準偏差 1.64 gf) であった。一方, 周囲 の健常粘膜（コントロール）の硬さ測定值は 1 . 48 2.68 gf, 平均 $2.11 \mathrm{gf}$ (標準偏差 $0.45 \mathrm{gf}$ ) で, いずれも病変がコントロールを上回っていた。コ ントロールに対する病変の比は, $2.90 \sim 4.32$ 倍で 平均 3.36 倍と病変が高值を示した。病変とコント ロールの平均値の単位面積あたりの硬さ測定値は それぞれ $226.0 \mathrm{gf} / \mathrm{cm}^{2}\left(2.21 \times 10^{4} \mathrm{~Pa}\right), 67.2 \mathrm{gf} /$ $\mathrm{cm}^{2}\left(6.59 \times 10^{3} \mathrm{~Pa}\right)$ であった（表 $11 ） 。$

3) 扁平苔癬

扁平苔癬 5 例の硬さ測定值は $3.55 \sim 7.43 \mathrm{gf}$, 平

表 11 白板症の硬さ測定值

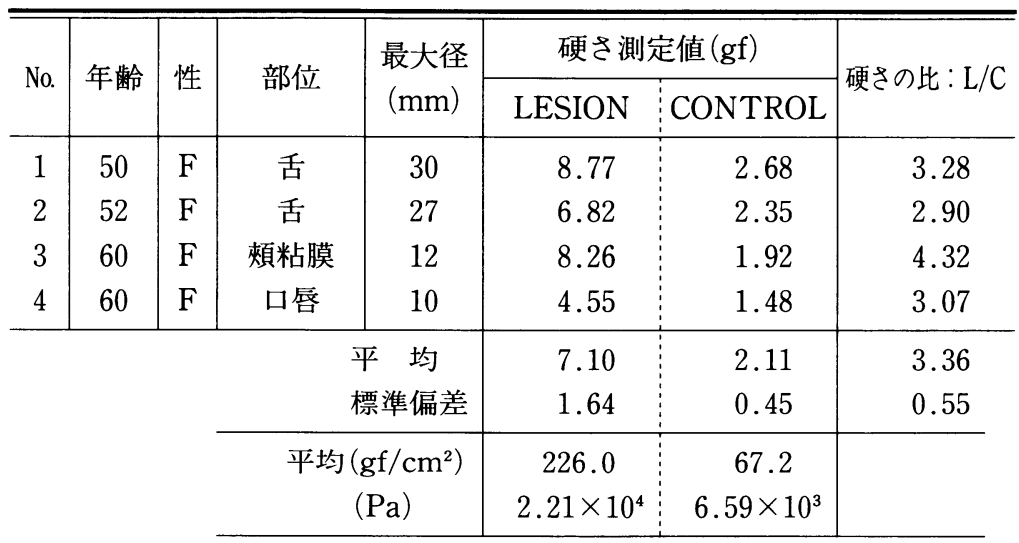


均 $5.57 \mathrm{gf}$ (標準偏差 $1.45 \mathrm{gf}$ ) であった。一方, 周 囲の健常粘膜（コントロール）の硬さ測定値は 2. 30 5.15 gf, 平均 3.74 gf, (標準偏差 1.39 gf) で, いずれも病変がコントロールを上回っていた。コ ントロールに対する病変の比は, 1.22 2.63 倍で 平均 1.49 倍といずれも病変が高值を示した。病変 とコントロールの平均値の単位面積あたりの硬さ 測定値はそれぞれ $177.3 \mathrm{gf} / \mathrm{cm}^{2}\left(1.74 \times 10^{4} \mathrm{~Pa}\right)$, $119.0 \mathrm{gf} / \mathrm{cm}^{2}\left(1.16 \times 10^{4} \mathrm{~Pa}\right)$ であった（表 $12 ） 。$

4) 切除材料（扁平上皮癌）

舌 2 例, 口底 2 例, 頪粘膜 1 例の切除前後の癌 と周囲健常粘膜の硬さ測定値を表 13 に示した。 癌の切除材料の硬さ測定值は, 生体では 22.

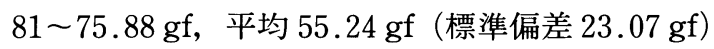
であり, 切除物では $22.00 〜 75.50 \mathrm{gf}$, 平均 53.25 gf (標準偏差 23.31 gf) であった。個々の症例の生 体と切除物の硬さ測定值の差は+0.81 +3.93 $\mathrm{gf}$ ，平均+1.99 gf (+3.74\%) であり，煩粘膜の 1 例 $+14.2 \%$ 除くと差はきわめて小さかった $(+1.85 \sim+3.68 \%)$ 。

コントロール（癌周囲の健常粘膜）の硬さ測定

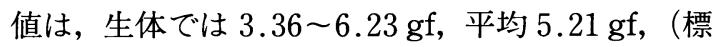
準偏差 1.00 gf）であり，切除物では $2.06 \sim 5.10$ gf, 平均 $3.90 \mathrm{gf}$ (標準偏差 $1.00 \mathrm{gf}$ ) であった。健 常粘膜では生体と切除物の差は+0.57〜+1.88 $\mathrm{gf}$, 平均 $+1.31 \mathrm{gf}(+33.6 \%)$ であり, 数值の差

表 12 扁平苔癬の硬さ測定值

\begin{tabular}{|c|c|c|c|c|c|c|c|}
\hline \multirow{2}{*}{ No. } & \multirow{2}{*}{ 年齢 } & \multirow{2}{*}{ 性 } & \multirow{2}{*}{ 部位 } & \multirow{2}{*}{$\begin{array}{c}\text { 最大径 } \\
(\mathrm{mm})\end{array}$} & \multicolumn{2}{|c|}{ 硬さ測定値 (gf) } & \multirow{2}{*}{ 硬さの比：L/C } \\
\hline & & & & & LESION & CONTROL & \\
\hline 1 & 52 & $\mathrm{~F}$ & 煩粘膜 & 12 & 6.30 & 5.15 & 1.22 \\
\hline 2 & 54 & $\mathrm{~F}$ & 煩粘膜 & 18 & 7.43 & 2.82 & 2.63 \\
\hline 3 & 68 & $\mathrm{~F}$ & 煩粘膜 & 14 & 5.04 & 3.29 & 1.53 \\
\hline 4 & 68 & $\mathrm{~F}$ & 煩粘膜 & 18 & 3.55 & 2.30 & 1.54 \\
\hline 5 & 59 & $\mathrm{~F}$ & 舌 & 20 & 5.55 & 4.00 & 1.39 \\
\hline \multicolumn{5}{|c|}{ 平均 } & 5.57 & 3.74 & 1.49 \\
\hline & & & \multicolumn{2}{|c|}{ 標準偏差 } & 1.45 & 1.39 & 0.50 \\
\hline & & & \multicolumn{2}{|c|}{$\begin{array}{c}\text { 平均 }\left(\mathrm{gf} / \mathrm{cm}^{2}\right) \\
(\mathrm{Pa})\end{array}$} & $\begin{array}{c}177.3 \\
1.74 \times 10^{4}\end{array}$ & $\begin{array}{c}119.0 \\
1.16 \times 10^{4}\end{array}$ & \\
\hline
\end{tabular}

表 13 口腔扁平上皮癌切除材料と生体の硬さ測定值

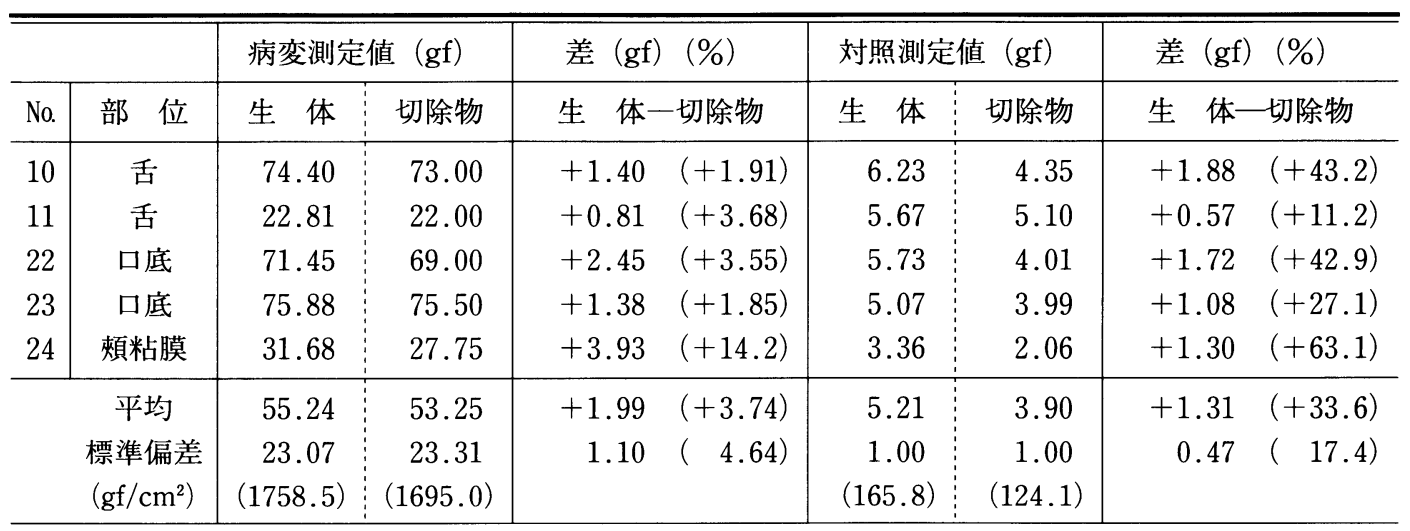


は少なかったが相対的誤差はやや大きかった。

\section{V. 考察}

口腔粘膜の硬さを物理的に測定した報告はきわ めて少なく, 義歯床下粘膜の粘弾性や被圧変位量 を測定した報告がみられるのみで6 8), 骨に直接裏 打ちされない可動部口腔粘膜や口腔癌の硬さを測 定した報告はみられない。生体の硬さ測定を目標 としてモデルまたは切除材料を試料として実験的 に試行された報告は, 張力試験 ${ }^{1)}$, 変位一荷重方 式 ${ }^{2)}$, マイクロマニピュレータ利用法 ${ }^{11)}$, 共振法 ${ }^{10)}$, 超音波法 ${ }^{3}$ などがある。なお，生体皮膚の硬さ測定 としては, 張力試験 ${ }^{13)}$, 変位一荷重方式 ${ }^{11,15,16,18)}$, 吸引法 ${ }^{1)}$, マイクロマニピュレータ利用法 ${ }^{11)}$, 共振 法 $^{12,14)}$, 超音波法4)などがあるが，これらは比較的 大掛かりな装置を必要とするため, 狭い口腔での 硬さ測定への応用は不可能であった。そこで，口 腔の硬さ測定には，変位一荷重方式を改良して応 用することを試みた。口腔内に適応を考慮すると 張力試験と吸引法は唾液の介在により使用困難か 不能であり，マイクロマニピュレータ利用法では 狭小な口腔内では操作できないなどから, 変位 一荷重方式を採用することとした。なお，悪性腫 瘍の硬さを経皮的に生体測定することを試みた方 法には, 乳癌を対象としてあらかじめ圧迫してお き,さらに圧迫した変位と荷重の関係から硬さを 測定する方法があり ${ }^{1)}$, 乳癌自動診断システムが 試作されている ${ }^{17)}$ 。また, 共振法により切除材料を 試料として癌組織と正常組織の硬さ測定を行った 報告もある1)。体腔内の粘膜の生体硬さを測定し た方法には，内視鏡下に歪センサーを胃壁に接触 させ圧迫により生じた反発応力を壁の硬さとした 方法 ${ }^{19)}$ や導電性ゴムを利用した二次元センサーに よって内臓壁の硬さ測定を試みた方法の報告20)な どがあるが，ともに再現性のある物理特性を得る にいたっていない。

一般に口腔扁平上皮癌は硬結を伴って硬いとい う認識があり，癌の診断および病変の広がりを決 定する根拠のひとつと考えられている。従来から 行われている硬さの診断はもっぱら指先の感覚,
触診に頼っており，診断者の熟練度によって異な ることも考えられ，病変の硬さを定量的に表現す ることはできなかった。また, 臨床上硬結を触知 しても病変相互の比較, 経時的観察は困難であっ た。本研究では, 硬さの客観化, 定量化を目的と しており，また，臨床で行う“触診”における硬 さ判定に近いという発想のもとに変位一荷重方式 を採用した。また，口腔環境の特殊性を考慮して， ある一定変位量に対する任意の圧接速度によって 生じる荷重を測定することで定量化の可能性を検 討した。試作装置を考案するにあたって，骨に裏 打ちされない口腔粘膜の硬度測定の問題点をあげ ると, 口腔に関しては, (1)唾液に覆われた狭い空 間である。(2)硬さには個体差，部位差がある。(3) 組織は粘膜であるため，探触子が鋭利なものでは 損傷する可能性がある。(4)表面の形態が複雑で平 坦でない。(5)筋肉の長時間の安静を得にくい, な どがあげられる。一方硬さ測定装置に関するもの では，(1)従来の器機は大型であり，口腔内の使用 に制限がある。(2)感染防止を考慮し探触子は滅菌 可能か, ディスポーザブルでなくてはならない。 (3)唾液に浸染するため探触子に電気的機構を組み 込みにくい。などがあげられる。

以上の問題を考慮して粘膜硬さ測定装置を考案 試作し, 実用に耐之得るものとなるよう改良を加 えた。

試作装置 1 を作製にあたっては，フリーハンド の圧接による荷重で硬さを定量化できると見込ん だが, 実際は探触子が直径 $4 \mathrm{~mm}$ であるのに対し て, 腫瘍は小さなものもあり，また硬い癌病変で は $2 \mathrm{~mm}$ 程度の変位が得られただけという予想 外の結果であった。

試作装置 2 では, 探触子の形態を直径 $2.5 \mathrm{~mm}$ に変更した。また，探触子にロードセルを利用し たが，ロードセルは測定機構が先端のへッド内に あるため柄部が歯や口唇に触れても測定可能と考 えられた。しかしながら，ロードセルは，滅菌す る方法がなく，使用に際して全体を被覆する必要 があり，ラテックスで被覆したため測定值に対す る影響は不明で，被覆により探触子の変位が読み 
取りにくくなる欠点があった。

試作装置 3 では，探触子にスプリングを組み込 むことで過度の圧接に対して粘膜を保護できるこ とと, 探触子の滅菌を可能とする目的で試作され た。内蔵するスプリングの弾性を 10 ～ 0 gf/3.5 $\mathrm{mm}$ で測定したところ, 健常舌では測定可能で あったが, 癌の一部では測定不能であった。また， 内蔵したスプリングは，微妙な荷重の差の変化を 測定するのには難点があり,精度に問題が残った。

試作装置 4 では, 試作装置 3 の結果から, 健常 粘膜と粘膜病変の測定がともに可能な装置となる よう調整し, 探触子の直径を $2 \mathrm{~mm}$, 変位量を 2 $\mathrm{mm}$ とした。この理由としては，変位量を大きく とりすぎると弾性率の線形性が低下し, 測定誤差 が大きくなる可能性があること，接触面積を大き くすると，小さな病変の測定は不可能であり，ま た，硬さを測定している部位の特定が臨床的に困 難となると考えたためである。探触子の直径と変 位量の決定に際しては，健常舌粘膜の圧痕残遺の 様相より，本装置の変位量を $2 \mathrm{~mm}$ と仮定してそ の 2 倍の安全域の $4 \mathrm{~mm}$ まで圧痕をつくらない 探触子の直径は $2 \mathrm{~mm}$ と考えられたため, 探触子 の変位量・直径ともに $2 \mathrm{~mm}$ とするのが妥当と考 えた。

試作装置をフリーハンドで操作することの長所 としては狭小な空間で，かつ平坦でない口腔粘膜 に, 短時間に, ほぼ正確な位置で, 表面に対して 垂直に探触子を定位できることである。短所とし ては，探触子の圧接速度が正確に一定とはいえな いことと, 変位量が正確に $2 \mathrm{~mm}$ とならない点が あげられるが，探触子の先端から $2 \mathrm{~mm}$ の位置に 補助板を設けたことにより, 変位量の誤差はかな り改善された。また, 硬さの測定精度ならびに再 現性を検討するために舌モデルを試作した。

シリコンゲルにて作製した舌モデルの永久圧縮 歪は，きわめて小さく，また，温度変化に伴う貯 蔵弾性率は変化を認めず十分安定した物性であ ク,サンプルの材料として好ましいと考えられた。 サンプル 1，2 と健常者の可動粘膜の硬さ測定值 を比較すると,サンプル 1 の硬さ測定值は $1.42 \mathrm{gf}$
で, 最も軟らかい粘膜に近似していると考えられ， サンプル 2 の $4.79 \mathrm{gf}$ は, 舌の平均值よりやや硬 い程度と考えられた。

圧接速度と荷重との関連について舌モデルを利 用して, 実験的に 3 種類の速度で測定したところ， 変位 $2 \mathrm{~mm}$ までは荷重と変位の関係は, $5 \sim 20$ $\mathrm{mm} / \mathrm{s}$ で比較的安定した線形を示しており，本研 究で用いたシリコンゲルのような粘弾性体であっ ても変位 $2 \mathrm{~mm}$ においては純弾性体に近い取り 扱いができることを示唆しており，圧接変位量を $2 \mathrm{~mm}$ とした測定では，その精度は十分確保され ると考えられた。

また，サンプルをフリーハンドで則定すること で測定誤差が生じる可能性が考えられたがサンプ ル 1 では 3 検査者の硬さ測定值の平均值は 1 . 41 1.44 gf（最大の標準偏差は 0.05 gf）でほとん ど差は認めず，ほぼ安定した成績と考えられた。 なおフフリーハンドによる圧接速度は $10 \mathrm{~mm} / \mathrm{sec}$ に近い值であると推定された。また，同様にサン プル 2 においても硬さ測定值にほとんど差を認め ず圧接速度 $10 \mathrm{~mm} / \mathrm{sec}$ に近い值であると推定さ れた。このことからフリーハンドによる圧接速度 は弾性率の 4 倍違うサンプル間であるにもかかわ らずほぼ等しいと推察された。

さて, 口腔粘膜の実際の硬さ測定を行うに際し, 測定回数による測定値の差を被験者 2 名の舌につ いて検討したが, $1 \sim 5,1 \sim 10,1 \sim 20$ 回の測 定値の平均值と標準偏差を比較すると，測定回数 が増えると標準偏差は,わずかに減少するものの, 平均值に差はなかった。したがって，あえて 20 回 の測定は不要と考え, 測定回数を 5 回とし平均值 で示した。

舌粘膜の測定条件については，舌の後方も測定 できるように舌尖の位置を下顎中切歯の位置から $0 \sim 40 \mathrm{~mm}$ 前方へ伸展させて測定值の変化を検 討したところ $20 \mathrm{~mm}$ 前方位まで $0 \mathrm{~mm}$ 位置に比 べ誤差は $10 \%$ 未満であり，この位置で測定を行う こととした。なお，舌癌の触診でも同様の位置に て測定することが多く実際の条件に一致している と考えられた。 
煩粘膜の硬さ測定に関して開口度による測定值 の変化を検討したところ中切歯間が $20 \mathrm{~mm}$ と 25 $\mathrm{mm}$ の比較では，誤差が $0.3 \mathrm{gf}(10 \%)$ 未満であっ たが， $30 \mathrm{~mm}$ を越えると大きく変化することか ら，開口度を 20〜25 mm とした。なお，実際の触 診でも $25 \mathrm{~mm}$ 程度の開口がないと楽に行えない ことから妥当であると考えられた。

口底では，軽く開口し舌を圧排する方法をとっ て測定し，通常は測定上問題なかったが，一部口 底が深く，下顎前歯によって妨げられるため正確 に測定することができなかった症例もみられた。

そこで, 探触子先端から柄部まで $35 \mathrm{~mm}$ ある $\mathrm{L}$ 字型の探触子を試作し口底を圧接できたが，変位 量を正確に読み取れなかった。これについては， 今後の検討が必要と思われた。

測定日により測定值が異なるか否か，健常者 2 名の舌を 1 日間隔で各 5 回 3 日間にわたって測定 したところ，誤差は $5 \%$ 未満であり再現性は優れ ていた。

測定者が異なった場合の精度についても健常者 2 名の舌を当科教室員 3 名が各 5 回測定し，平均 して算出した結果，測定者による誤差は $5 \%$ 未満 と少なく, 再現性, 精度ともに優れていた。

本法による健常者 25 名の口腔粘膜の硬さにつ いては, 舌で最小 $2.39 \sim 6.78 \mathrm{gf}$ で平均 $4.45 \mathrm{gf}$ (標準偏差 1.16 gf), 口底では, 最小 2.00 最大 $6.26 \mathrm{gf}$ で平均 $4.33 \mathrm{gf}$ (標準偏差 $1.28 \mathrm{gf}$ ), 頓粘膜 では，最小 1.40 最大 $5.27 \mathrm{gf}$ で平均 $2.96 \mathrm{gf}($ 標 準偏差 $0.80 \mathrm{gf}$ ) であった。この結果, 舌が最も硬 く, 次いで口底, 煩粘膜の順であった。口底では,
前述の理由で 8 例が測定できなかった。舌と口底， 口底と頓粘膜の間に各々 $0.1 \%$ 未満の危険率で有 意差が認められ，頓粘膜が最も軟らかいという結 果であった。臨床経験上，触診でも煩粘膜が軟ら かいと思われたがそれを裏付ける結果となった。

舌扁平上皮癌の硬さについては，最小 13 .

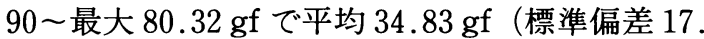
22 gf）であった。この值は明らかに健常者よりも 高值であった。病変／コントロール (周囲粘膜) 比は, $2.31 \sim 16.29$ 倍, 平均 6.97 倍であり癌と周 囲粘膜に明らかな差を認め, 臨床上癌の診断に有 用であることが示唆された。また，白板症 4 例の 硬さについては，最小 4.55 最大 $8.77 \mathrm{gf} て ゙$ 平均 $7.10 \mathrm{gf}$ (標準偏差 1.64 gf) で，病変／コントロー ル比は, $2.90 \sim 4.32$ 倍, 平均 3.36 倍であり, 扁平 苔癖 5 例の硬さについては, 最小 3.55 最大 7.43 gf で平均 5.57 gf（標準偏差 1.45 gf）で，病変／ コントロール比は, $1.22 \sim 2.63$ 倍, 平均 1.49 倍で あり, 白板症, 扁平苔痽ともにやや硬い傾向で, 硬さは癌, 白板症, 扁平苔癖, 健常粘膜の順であ ク，臨床上の経験とも一致していた(表 14)。推計 学的 ( $\mathrm{t}$ 検定, Wilcoxon 検定) に癌と健常粘膜は 有意差を認めた $(\mathrm{p}<0.001)$ 。扁平苔癬と白板症に

表 14 疾患別硬さ測定値

\begin{tabular}{l|r|c}
\hline \hline \multicolumn{1}{c|}{ 对 象 } & 例数 & 測定平均值 $\pm \mathrm{SD}(\mathrm{gf})$ \\
\hline 健常者（舌） & 25 & $4.45 \pm 1.16$ \\
扁平苔㾕 & 5 & $5.57 \pm 1.45$ \\
白板症 & 4 & $7.10 \pm 1.64$ \\
癌（舌） & 20 & $34.83 \pm 17.22$ \\
\hline
\end{tabular}

表 15 圧接速度別歪換算

\begin{tabular}{c|c|c|c|c|c}
\hline \hline サンプル & 圧接速度 $(\mathrm{mm} / \mathrm{s})$ & 測定值 $(\mathrm{gf})$ & 応力 $\left(\mathrm{gf} / \mathrm{cm}^{2}(=\times 98 \mathrm{~Pa})\right)$ & 弾性率 & 歪 $(\%)$ \\
\hline \multirow{3}{*}{1} & 5 & 1.25 & $39.8\left(3.90 \times 10^{3}\right)$ & & 41 \\
& 10 & 1.40 & $44.6\left(4.37 \times 10^{3}\right)$ & $9.40 \times 10^{3}$ & 46 \\
& 20 & 1.63 & $51.9\left(5.08 \times 10^{3}\right)$ & & 54 \\
\hline \multirow{3}{*}{2} & 5 & 3.88 & $123.5\left(1.21 \times 10^{4}\right)$ & & 32 \\
& 10 & 4.59 & $146.1\left(1.43 \times 10^{4}\right)$ & $3.80 \times 10^{4}$ & 38 \\
& 20 & 5.13 & $163.3\left(1.60 \times 10^{4}\right)$ & & 42 \\
\hline
\end{tabular}




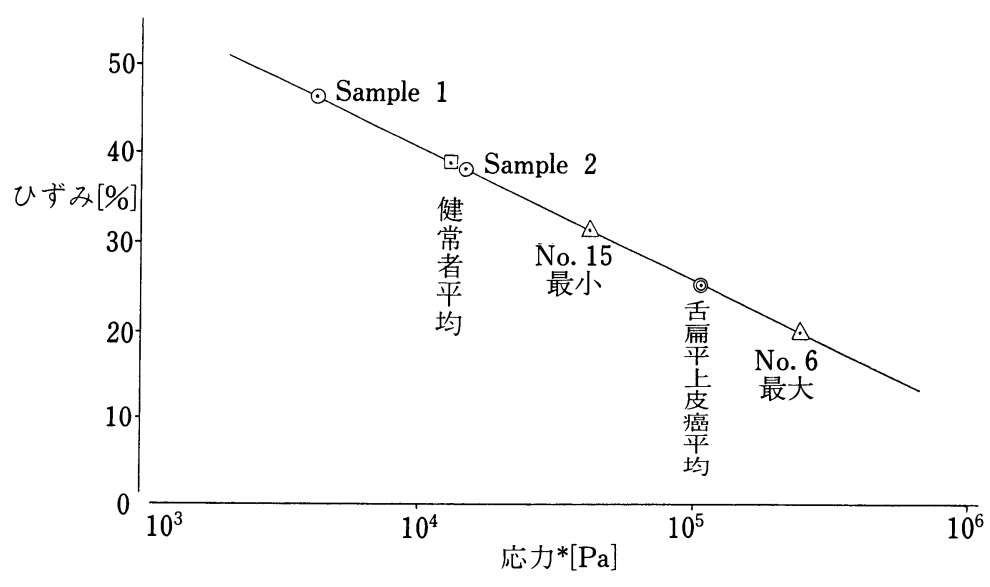

*各種異なった弾性率をもつシリコンゲルの発生応力

図 23 検量線（各シリコンゲル変位 $2 \mathrm{~mm}$ 発生応力とひずみとの相関） 速度 $10 \mathrm{~mm} / \mathrm{s}$

は例数が少なく推計処理をするにはいたらなかっ た。

なお，測定方法の妥当性を検討する目的でシリ コンゲル 2 種を用いて, $2 \mathrm{~mm}$ の変位 (圧接速度= $10 \mathrm{~mm} / \mathrm{sec}$ ：フリーハンドの圧接速度に近似）が どれくらいの歪に相当するかを下式より算出し, 歪量と発生応力の検量線を作成した（表 15, 困 23)。

$$
\begin{aligned}
& \mathrm{E}=\mathrm{P} / \delta \\
& \therefore \delta=\mathrm{P} / \mathrm{E}
\end{aligned}
$$

$\mathrm{E}:$ 弾性率, $\mathrm{P}:$ 応力, $\delta:$ 歪

さらにその歪量と発生応力の検量線を舌などに も適用できると仮定して, 舌における発生応力か ら弾性率を推定した（表 16）。

変位量 $2 \mathrm{~mm}$ に相当する歪は, 検体が硬いほど
小さくなることがわかった。よって得られる発生 応力と推定される弾性率の関係は, 高い発生応力 側へいくほど高い弾性率のほうへずれていくこと がわかった(図 24)。検量線作成に用いたシリコン ゲル弾性率 $9.4 \times 10^{3}, 3.8 \times 10^{4}$ の範囲近傍で, 信頼 性の高い弾性率の予想が可能と考えられた。さら にシリコンゲルの弾性率をもっと広い範囲で取れ ばそれに応じて, 広範囲の検体の弾性率の予測が 可能になると考えられた。よって, 本法による硬 さ測定法は物性值に換算可能な測定手技であるこ とが確かめられた。

以上より, 本法による硬さ測定法により従来不 可能と思われていた可動口腔粘膜の硬さを客観 的, 定量的に測定することが可能となり癌を中心 とする口腔粘膜病変の診断の一助として有用であ

表 16 検量線による検体推定弾性率

\begin{tabular}{l|c|c|c|c|c}
\hline \hline \multicolumn{1}{c|}{ 舌 } & 圧接速度 & 測定値 $(\mathrm{gf})$ & 応力 $\left(\mathrm{gf} / \mathrm{cm}^{2}(=\times 98 \mathrm{~Pa})\right)$ & 弾性率 & 歪 $(\%)$ \\
\hline 健常者平均值 & & 4.45 & $141.6\left(1.38 \times 10^{4}\right)$ & $3.60 \times 10^{4}$ & 38 \\
扁平上皮癌平均值 & & 34.8 & $1,108\left(1.90 \times 10^{5}\right)$ & $4.36 \times 10^{5}$ & 25 \\
No.15(最小) & \multirow{2}{*}{$10(\mathrm{~mm} / \mathrm{s})$} & 13.9 & $442.5\left(4.34 \times 10^{4}\right)$ & $1.36 \times 10^{5}$ & 32 \\
No.6 (最大) & & 80.32 & $2,557\left(2.51 \times 10^{5}\right)$ & $1.26 \times 10^{6}$ & 20 \\
\hline
\end{tabular}




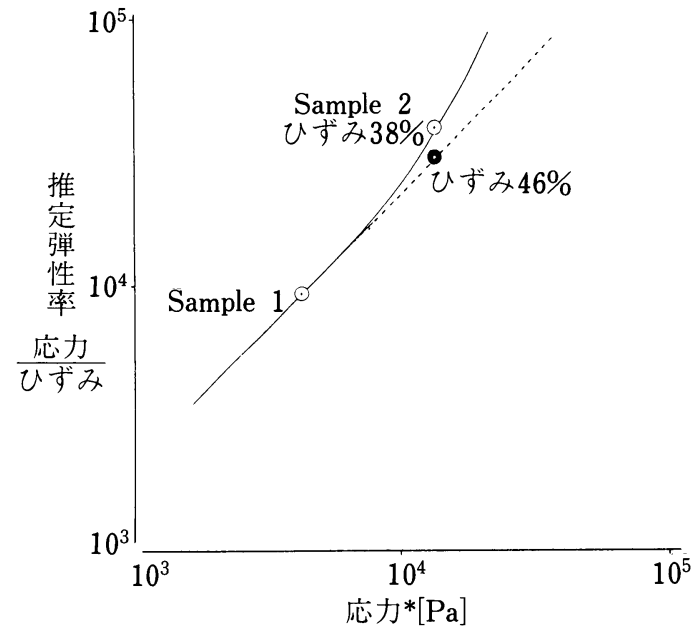

*各種異なった弾性率をもつシリコンゲルの発生応力 図 24 検量線（各シリコンゲル変位 $2 \mathrm{~mm}$ 発生応 速度 $10 \mathrm{~mm} / \mathrm{s}$

力と推定弾性率との相関)

ることが示唆された。

\section{VI. 結語}

従来不可能と考えられていた骨に支持されない 可動部粘膜の硬さを定量的に測定し, 臨床応用す る目的で口腔粘膜硬さ測定装置を試作し，健常粘 膜, 扁平上皮癌および類似病変を測定し，以下の ような結果を得た。

\section{1. 口腔粘膜硬さ測定装置について}

1）歪ゲージに直径 $2 \mathrm{~mm}$ の探触子を取り付 け，フリーハンドで粘膜に $2 \mathrm{~mm}$ 圧接し，生じた 荷重を測定する硬さ測定装置を考案試作し，硬さ を定量的に測定できることが明らかとなった。

なお，本探触子先端の形状が口腔粘膜に損傷や 凹みを生じさせないことを確認した。

2）測定条件としては, 舌では, 開口度を 30〜 40 mm とし, 舌尖を把持し $20 \mathrm{~mm}$ 伸展させ た位置で測定し，頪粘膜では開口度を $20 \sim 25 \mathrm{~mm}$ として測定した。口底では, 開口度を $30 \sim 40 \mathrm{~mm}$ とし, 舌を軽く反対側斜め後方に圧排して測定し た。
3）本法の測定者による差，測定日による差を 検討したところ，ほとんど差はみられず再現性が 優れていた。なお, 測定回数は 5 回とし, 平均值 で示すのが妥当と判断された。

4）舌モデルを使用した基礎的実験においても フリーハンドで $2 \mathrm{~mm}$ 圧接する本硬さ測定法は 精度，再現性ともに優れ，実用上䛊差は許容範囲 にあることが確認された。

\section{2. 健常粘膜の硬さ}

口腔粘膜に異常を認めない 24 48 歳の男女 25 名の舌，口底，頓粘膜の硬さは舌では，2.39〜6. $78 \mathrm{gf}$, 平均 $4.45 \mathrm{gf}$ (標準偏差 $1.16 \mathrm{gf}$ )，口底では

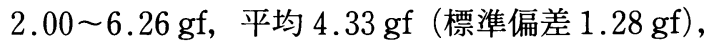
頪粘膜では, $1.40 \sim 5.27 \mathrm{gf}$, 平均 $2.96 \mathrm{gf}$ (標準偏 差 $0.80 \mathrm{gf}$ ) であった。舌が最も硬く， 口底，頓粘 膜と続き頪粘膜と他の部位に有意差を認めた $(\mathrm{p}<0.001)$ 。なお，口底の 8 例では，口底が深い ため正確な測定值が得られなかった。

\section{3. 扁平上皮癌の硬さ}

舌扁平上皮癌 20 例の硬さは, $13.90 \sim 80.32 \mathrm{gf}$, 平均 $34.83 \mathrm{gf}$ (標準偏差 $17.22 \mathrm{gf}$ ) で, 口底扁平上 皮癌 3 例の測定值は $32.47 \sim 75.88 \mathrm{gf}$, 平均 59.93 gf (標準偏差 19.50 gf) で, 頓粘膜扁平上皮癌 3 例

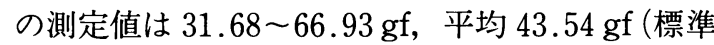
偏差 16.54 gf) であり, 癌の発症部位による硬さの 差は明らかでないが，癌特有の硬さがあることが 推察された。また, 舌癌の硬さは, 周囲健常粘膜 および健常者の粘膜に比べて明らかに高值であ ク, 0.1\%未満の危険率にて推計学的に有意差が認 められた。病変/コントロール比は, 舌で, 2 . $31 \sim 16.29$ 倍 (平均 6.97 倍), 口底で, 5.12 14. 96 倍 (平均 10.85 倍), 煩粘膜で, 5.60 19.06 倍 (平均 10.39 倍) であった。

\section{4. 腫痀以外の粘膜疾患の硬さ}

白板症 4 例の硬さは $4.55 \sim 8.77 \mathrm{gf}$, 平均 7.10 gf（標準偏差 $1.64 \mathrm{gf}$ ) でコントロールに対する病 変の比は, $2.90 \sim 4.32$ 倍で平均 3.36 倍と病変が 硬かった。

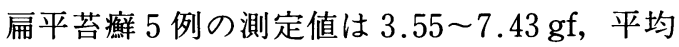
5.57 gf (標準偏差 1.45 gf) で，コントロールに対 
する病変の比は, $1.22 \sim 2.63$ 倍で平均 1.49 倍で あり病変がやや硬かった。

以上の硬さを弾性率に換算すると, 舌扁平上皮 癌の平均値の推定弾性率は $4.36 \times 10^{5} \mathrm{~Pa}$, 舌健常 粘膜の平均值の推定弾性率は $3.60 \times 10^{4} \mathrm{~Pa}$ で あった。

以上，試作した口腔粘膜硬さ測定装置により従 来不可能であった口腔可動粘膜の硬さを定量的に 測定することが可能となり，各種口腔疾患の診断 および治療に有用であることが示唆された。

\section{謝辞}

稿を終えるに臨み，終始ご愁篤なるご指導とご校閲 を賜りました東京医科歯科大学歯学部口腔外科学第 1 講座天笠光雄教授に深甚なる謝意を捧げます。ま た，ご校閲を賜りました本学歯科理工学第 1 講座西村 文夫教授に感謝申し上げます。あわせて，数々のご協 力とご援助をいただきました総合計装株式会社 鈴木 勝氏, 東燃化学株式会社 藤井茂夫氏, 株式会社リガク 平山泰生氏, 株式会社北里サプライ 山田泰嗣氏に厚 くお礼申し上げます。また，研究にご協力いただきま した東京医科歯科大学歯学部口腔外科学第 1 講座 岩城 博講師および教室員各位に厚くお礼申し上げ ます。

なお, 本研究の要旨の一部は, 第 47 回日本口腔科学 会総会(平成 5 年 5 月 14 日, 弘前), 第 58 回口腔病学 会学術大会 (平成 5 年 11 月 27 日, 東京) において発 表した。

本研究の一部は平成 $4 \sim 6$ 年度文部省科学研究費 補助金 (一般 B) No.00014332, 同一般 C (No.63570930, および喫煙科学財団研究補助金（1989 1993 年）に よった。

\section{文献}

1）高谷 治, 赤塚孝雄：生体硬さの臨床的測定法. 計測と制御 $14: 281-292 ， 1975$.

2）杉本恒美，上羽貞行，伊藤紘一：緩和弾性率を用 いた生体組織の硬さの一評価法一計測理論と in vitro モデル実験による検討一. 医用電子と生体 工学 29:269-275, 1991.

3）杉本恒美, 上羽貞行, 伊藤紘一：集束超音波を用 いた生体組織の計測に関する基礎的研究 (II). 日 本超音波医学会講演論文集：319-320，1992.

4) Yamakoshi, Y., Sato, J. and Sato T. : Ultrasonic imaging of internal vibration of soft tis- sue under forced vibration. IEEE Trans. Sonic Ultrason. 37：45-53, 1990 .

5）平山泰生：動的粘弾性による材料分析. 接着 $35: 198-209,1990$.

6）谷田部優：上顎粘膜の動的粘弾性測定に関する 研究。口病誌 $58: 74-94,1991$.

7) Tomlin, H. R., Wilson, H. J. and Osborne, J. : The thickness and hardness of soft tissues. Brit. Dent. J. 124 : 223-226, 1968.

8）宮下恒太：顎粘膜の局所被圧変位度と咬合力に よる義歯床の沈下度とに関する研究. 歯科学報 $70: 38-68,1970$.

9）中原一郎：材料力学(下巻). 東京, 1990, 養賢堂, $116-121$

10) Omata, S. : New type transducer for measuring contact compliances of a soft body. J. Acoust. Son. Am. 78 : 1-5, 1985.

11）真島澄子，松島晧三，竹原直樹：サーボマイクロ マニピュレータを用いた生体組織の硬さの測定 とファジ一論的硬さの評価. バイオメカニズム学 会誌 $15 ： 42-48,1991$.

12）岡 久雄，入江 隆，松崎賢士，山本辰馬：皮膚 表面からみた硬さの定量化. 信学技報 91 ： 59-64, 1991

13）土屋和興，立花隆夫，戸田憲一，今村貞夫，風間 修：トランスデューサーを用いた皮膚硬化度測 定機の試作。日皮会誌 92：971-975, 1982.

14）尾股定夫：硬さ知覚用触覚センサの開発. センサ 技術 9：27-31，1990。

15）高橋元次：皮膚科に応用し得る $\mathrm{ME}$ 器機。臨皮 $45: 93-98$

16）木山喬博，岩月宏康，伊藤麻子，太田敏幸，金井 章：生体軟部組織の硬さ測定器の試作. 理学療法 学 $19: 122-127,1992$.

17）加藤一郎，笠木勝典，本間徹二，岡野敦夫，佐藤 伸雄：乳房自動診断システムに関する研究 (切除 標本)。バイオメカニズム 5 . 東京, 東大出版会, 96-101.

18）梅屋潤一郎，高須恵美子：皮膚のレオロジ一，セ ラミックス 28:1161-1167, 1993

19）西蔵ツワン，勝 健一，矢部 論，田島かほる, 伊藤 進：内視鏡下での歪みセンサーによる硬 度測定の検討. 消化器内視鏡の進歩 $34: 89-91$, 1989.

20）吉田和弘，林輝：癌触診を目的とした柔軟体 の硬度分布測定センサの研究ーバルーン式セン サの提案と実験的検討一, 精密工学会誌 58 : 1893-1898, 1992. 